PNL- -8218

DE93 004631

SUMMARY OF THE GOVERNMENT/INDUSTRY WORKSHOP ON NEW MATERIALS AND

PROCESSING TECHNOLOGIES FOR

INDUSTRIAL APPLICATIONS

J. K. Young

July 1992

Prepared for the U.S. Department of Energy under Contract DE-ACO6-76RLO 1830

Pacific Northwest Laboratory

Richland, Washington 99352
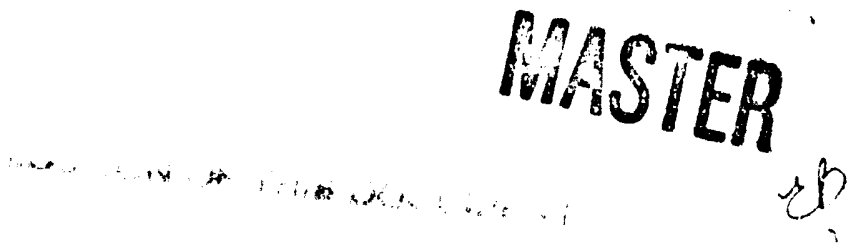


\section{EXECUTIVE SUMMARY}

This report presents a summary of the 1-day workshop conducted at Ann Arbor, Michigan, on April 16, 1992, between the National Center for Manufacturing Sciences (NCMS) and the U.S. Department of Energy Advanced Industrial Materials Program (DOE AIM). The workshop objectives were to: 1) encourage collaboration between DOE, the DOE national laboratories, and NCMS material manufacturers and 2) assist the DOE AIM program in targeting research and development (R\&D) more effectively.

During the workshop, participants from industry and DOE laboratories were divided into three working groups. Representatives from the DOE national laboratories currently conducting major research programs for AIM were asked to be working group leaders. The groups developed recommendations for NCMS and AIM managers using a six-step process.

As a result of the workshop, the groups identified problems of key concern to NCMS member companies and promising materials and processes to meet industry needs. Overall, the workshop found that the research agenda of DOE AIM should include working with suppliers to develop manufacturing technology. The agenda should not be silely driven by energy considerations, but rather it should be driven by industry needs. The role of DOE should be to ensure that energy-efficient technology is available to meet these needs. 


\section{CONTENTS}

EXECUTIVE SUMMARY . . . . . . . . . . . . . . . . . . . . . . iii

1.0 INTRODUCTION . . . . . . . . . . . . . . . . . . . . . 1.1

2.0 NATIONAL CENTER FOR MANUFACTURING SCIENCES . . . . . . . . . . . 2.1

3.0 ADVANCED INDUSTRIAL MATERIALS PROGRAM . . . . . . . . . . . . . . 3.1

4.0 INDIVIDUAL WORKING GROUP MEETINGS . . . . . . . . . . . . . . . . 4.1

4.1 PLASTICS RECYCLING, ORGANIC POLYMERS, AND BIOBASED
MATERIALS . . . . . . . . . . . .

4.1.1 Identification of Industry Problems . . . . . . 4.2

4.1.2 Technologies to Solve Problems . . . . . . . . . 4.2

4.1.3 Next Actions ................. . . 4.3

4.2 SURFACE MODIFICATION ................... 4.3

4.2.1 Identification of Industry Problems . . . . . . 4.3

4.2.2 Technologies to Solve Problems . . . . . . . . . 4.4

4.2.3 Next Actions .. . . . . . . . . . . . . . . 4.5

4.3 CERAMICS, INTERMETALLICS, AND METALS . . . . . . . . . 4.5

4.3.1 Identification of Industry Problems . . . . . . 4.6

4.3.2 Technologies to Solve Problems . . . . . . . . . 4.6

4.3.3 Next Actions ................... 4.7

5.0 CONCLUSIONS . . . . . . . . . . . . . . . . . . . . . . 5.1

APPENDIX A - WORKSHOP PRESENTATIONS . . . . . . . . . . . . . . A.I

APPENDIX B - LIST OF ATTENDEES . . . . . . . . . . . . . . . . . . B. 1 


\subsection{INTRODUCTION}

A 1-day workshop was conducted on April 16, 1992, between the National Center for Manufacturing Sciences (NCMS) and the U.S. Department of Energy Advanced Industrial Materials Program (DOE AIM). The workshop was organized under the auspices of the DOE Advanced Industrial Concepts Division (AICD) Systems Analysis Project, managed by Pacific Northwest Laboratory. (a) There were two objectives of this workshop: 1) to encourage collaboration between DOE, the DOE national laboratories, and NCMS material manufacturers and 2) to assist the DOE AIM program in targeting research and development (R\&D) more effectively.

The NCMS currently focuses on supporting technology development and deployment in several strategic areas, including environmentally conscious manufacturing, manufacturing processes and materials, product equipment and design, and management processes. NCMS prepared presentations at the workshop for each of these initiatives. An agenda is shown in Figure 1.1. Industrial participants from two member companies also attended the meeting (Ford and General Motors [GM]). A presentation was given by David Andres of General Motors (GM) describing the strategy for future collaboration between GM and the DOE national laboratories.

Representatives from the DOE national laboratories currently conducting major research programs for AIM were asked to be working group leaders. At the request of NCMS, working groups were organized under existing AIM research areas. However, the discussions within these working groups were primarily concerned with industry problems and were not confined by existing AIM research areas.

This workshop summary was prepared to ensure the workshop recommendations are available to all potential and existing AIM principal investigators within the DOE national laboratories and industry. Appendix A contains the

(a) Pacific Northwest Laboratory is operated for the U.S. Department of Energy by Battelle Memorial Institute under Contract DE-AC06-76RLO 1830. 
viewgraphs from the presentations. Appendix B contains a list of participants. This summary presents the recommendations of the working groups only; it does not represent the strategic viewpoint of AIM management. Information from the workshop represents valuable input to the strategic plan for AICD.

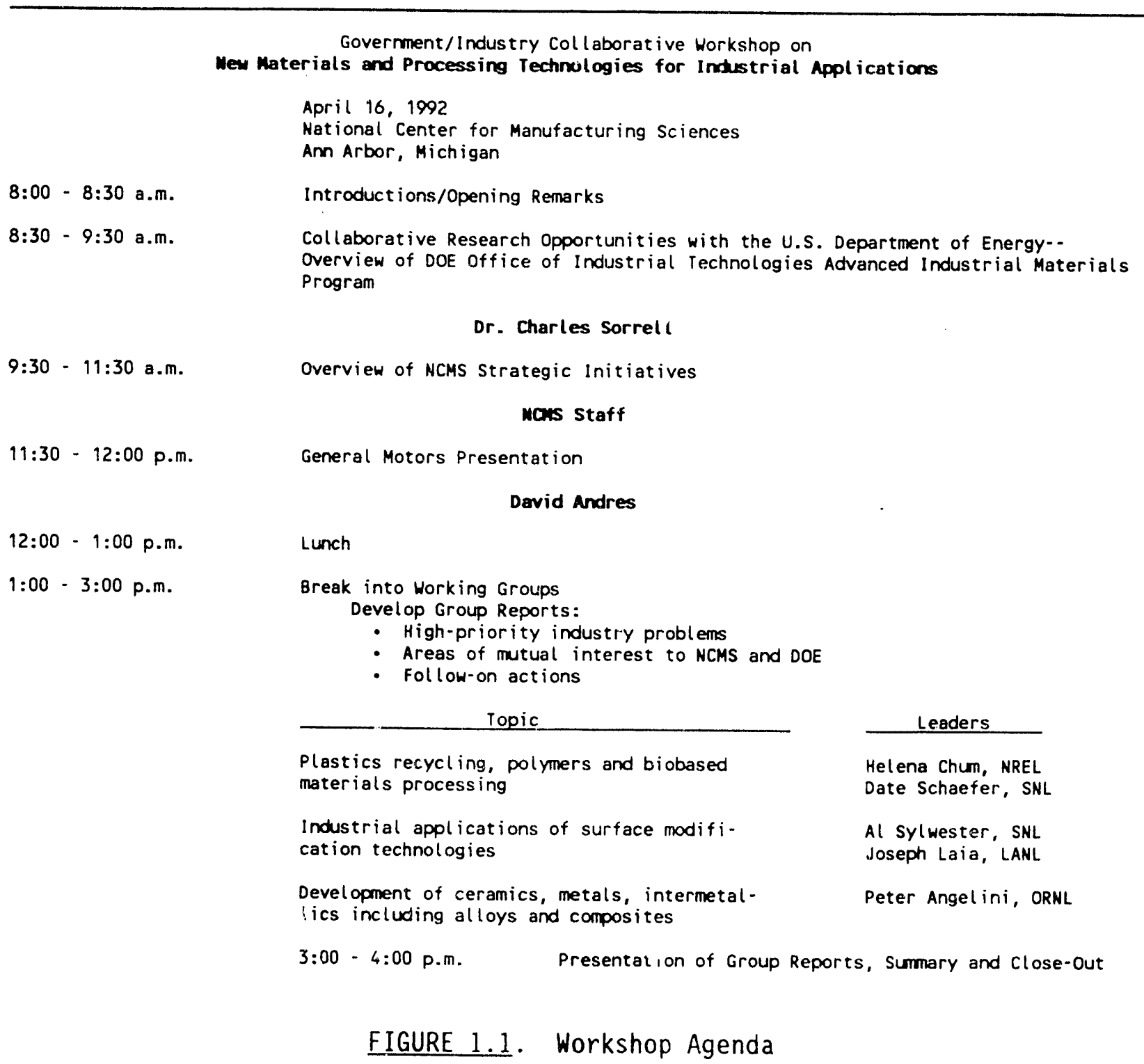




\subsection{NATIONAL CENTER FOR MANUFACTURING SCIENCES}

The NCMS is a not-for-pro.it collaborative research, development, and technology transfer corporation organized under the National Cooperative Research Act of 1984 and incorporated under the laws of the State of Delaware. NCMS consists of 125 member companies with plans for 150 small manufacturing applications centers. The role of NCMS is to establish a national R\&D agenda for advanced manufacturing. Last year, NCMS created the International Center for Manufacturing Sciences (ICMS) which seeks to enhance the business competitiveness of North American membership through collaboration with international research organizations.

Collaboration is the foundation of NCMS's mission, charter, and initiatives. NCMS members identify initiatives to pursue, define the resources needed, and form the teams to execute them. NCMS staff works with member companies to establish collaborative research initiative programs by forming teams to execute them.

The DOE and the DOE Taboratories are ex-officio members of NCMS. Through mechanisms such as the Cooperative Research and Development Agreement (CRADA) that NCMS has with several DOE laboratories, NCMS members perceive a significant role for government agencies to develop and exchange manufacturing $R \& D$ information with industry. However, there is a strong need for the DOE national laboratories to identify the areas where they have special expertise that can be used by NCMS.

The NCMS research agenda is currently divided among the following five Strategic Initiative Groups:

- Computer-Integrated Operations: concerned with information technology and systems, as required for the efficient creation and definition of product, engineering, operating, and manufacturing data

- Manufacturing Processes and Materials: seeks rational applications of enhanced and/or innovative process technologies, and the rapid adoption and utilization of new material technologies 
- Production Equipment and Systems: conducts activities to foster both incremental and next-generation advances of manufacturing equipment

- Management Practices: addresses important business concerns, such as education, training, accounting practices, and quality

- Environmental Conscious Manufacturing: manages a portfolio of activities to resolve the manufacturing-related environmental concerns of NCMS members.

Presentations were given by NCMS members in each of these areas. These initiatives are described more fully by the viewgraphs provided in Appendix $A$. The strategic initiatives in Manufacturing Processes and Materials and Environmentally Conscious Manufacturing seem to be particularly relevant to the AIM research agenda.

The NCMS Technology Sourcing Manager, Mr. John Sheridan, described the efforts of NCMS to negotiate the CRADA between the DOE and NCMS pursuant to the Memorandum of Understanding (MOU) sigried on July 25, 1991. The CRADA will serve as the master terms and conditions for cooperative research projects between NCMS and the DOE national laboratories. Eight of the 10 signatures needed for the CRADA to become legal have been obtained to date. As individual research projects are identified under the CRADA, the DOE national laboratories will provide descriptions of the work to be performed to the DOE field office contracting officer for final approval.

The CRADA has the following features that facilitate increased cooperation between DOE and the private sector: 1) points of contacts and strategic initiatives of interest to DOE and NCMS are identified; 2) issues of intellectual property, conflict-of-interest, and protection of proprietary information are negotiated; and 3) only signatures of DOE field office contracting officers are required before work can be initiated.

Many DOE national laboratories may participate in the CRADA. A "bottomup" approach is recommended as the best way to become involved in joint DOE/NCMS projects. This approach begins with the negotiation of a statement of work that later forms part of the CRADA agreement. 
To facilitate the TCI, DOE has developed a laboratory coordination board with the managers of technology transfer offices from Oak Ridge National Laboratory (ORNL), Los Alamos National Laboratory (LANL), Sandia National Laboratories (SNL), and Lawrence Livermore National Laboratory (LLNL). Members on the coordination board have identified individuals at their laboratories to serve as central points of contact in several specific areas. Five Technology Area Coordinating Teams (TACTS) have been formed to date. 


\subsection{ADVANCED INDUSTRIAL MATERIALS PROGRAM}

The mission of AICD is to develop and maintain a balanced program of high-risk, long-term, directed interdisciplinary research and exploratory development for the industrial sector. ${ }^{\text {(a) }}$ AICD is responsible for proving evidence of technical feasibility for advanced industrial concepts in materials and processing as well as combustion, thermal sciences, and biological and chemical processing.

AIM develops a technology base of advanced materials and processing technologies that will allow U.S. industry to achieve increased energy productivity by increasing the reliability, durability, and service life of industrial products and processes. In addition, AIM seeks to develop less energy-intensive materials processing methods that also use less expensive raw materials, fewer processing steps, and produce less waste. The current focus is in two key areas:

- Engineered Industrial Materials - e.g., intermetallic alloys, crack-resistant composites, thermal insulators, and innovative materials.

- Materials Processing Technologies - e.g., microwave processing, surface modification, plastic recycling, biobased materials processing, and innovative processing.

Current activities being funded at the DOE national laboratories are listed in Dr. Sorrell's presentation in Appendix A.

The research agenda of AIM is changing rapidly. New initiatives are being considered in the following areas:

- multifunctional foams and membrane materials

- intermetallic bonded oxides and carbides

- protective and functional surfaces for plastics, metals, and ceramics

- in-situ processing of composites.

(a) The AIM supports the AICD of the DOE Office of Industrial Technology (OIT) of the Office of Conservation and Renewable Energy (CE). 
AIM managers seek to 1) identify the materials research and development needs of industry and 2) conduct cooperative research and development with industrial firms to meet these needs. An example of this commitment is the CRADA between the GM Saginaw Division and ORNL. The $\$ 1.3$ million joint research effort will determine if nickel aluminide intermetallic alloys can be subjected to the intense and prolonged heat of industrial furnaces for hardening metal automobile and truck components. The CRADA was signed in only 15 days after representatives from ORNL met with GM officials. ORNL researchers developed nickel aluminide intermetallics in the mid-1980s, with funding from both DOE.CE and Basic Energy Sciences (BES). Approximately 30 months of testing will be conducted at both ORNL and GM Saginaw to evaluate if nickel aluminides can be used in industrial carburizing furnaces.

To get industry input, AIM managers recognize that they must work with industry at all levels (i.e., government policymakers, managers, and researchers). Policymakers must be aware that collaborative R\&D with industry is not just a matter of increasing the budget. Mechanisms must be established that support industry needs. For example, U.S. industries prefer to work closely with the suppliers of technology rather than directly with competitors. CRADAs legally support such collaboration, but it remains to be seen if this will be politically acceptable.

Industrial managers must work with their technical staff to identify their R\&D needs. Ideally, these needs should be prioritized and consolidated before meeting with representatives from DOE laboratories. Visits and staff exchanges with the DOE laboratories will facilitate one-to-one technical interactions so that collaborative opportunities can be identified. Identification of these opportunities will enable licensing, subcontracts, and CRADAs to be made available for industry to access the technology and capabilities of the DOE laboratories. However, the goals of these projects must overlap with the missions and objectives of the AIM program, if the project is to be considered for potential AIM funding. 


\subsection{INDIVIDUAL WORKING GROUP MEETINGS}

Participants were divided into the following three working groups:

- plastics recycling, organic polymers, and biobased processing

- surface modification technologies

- ceramics, intermetallics, and metals (including alloys and composites).

Working groups were asked to develop recommendations for NCMS and AIM managers using the following six-step process:

1. List high-priority industry problems that could be solved by new and improved materials and processing technologies--limit to about five problems.

2. Identify candidate materials and processing technologies that could be used to solve the problems identified in step 1--limit to two or three per problem.

3. Identify promising applied research and exploratory development activities needed for the technologies identified in step 2.

4. Prioritize the activities 1 isted in step 3 (e.g., Which activities are needed the most? Which activities are of joint interest to DOE and NCMS?).

5. Recommend a set of follow-on actions for the top two or three activities listed in step 4.

6. Prepare a 15-minute presentation of results for the close-out session. The presentation should include a list of high-priority industry problems, list of candidate materials and processing technologies to solve each high-priority problem, and recommendations for follow-on actions.

Summaries of the working group conclusions and recommendations are provided in the following sections.

\subsection{PLASTICS RECYCLING, ORGANIC POLYMERS, AND BIOBASED MATERIALS}

This working group included the following members:

- Helena Chum, National Renewable Energy Lab (NREL), co-leader

- Dale Schaefer, SNL, co-leader 
- Michael Wixom, NCMS

- James Anderson, Ford Motor Company

\subsubsection{Identification of Industry Problems}

To target industry needs in materials R\&D, AIM managers must understand the regulatory drivers. Some important drivers for the automotive manufacturing industry are 1) the proposed Corporate Automobile Fuel Efficiency (CAFE) standards, 2) the recycling legislation being passed in Germany and Japan, and 3 ) the need for products and manufacturing processes that use recycled materials. CAFE legislation would require the development of lighter, more fuel-efficient passenger vehicles.

German recycling legislation requires that all cars introduced after 1993 must be taken back and recycled hy the original manufacturers. Similar legislation is being drafted by the European Economic Community (EEC), Japan, and possibly the United States. Even if similar legislation is not passed in the United States, this legislation would be effective trade barrier to cars manufactured in the U.S. unless they could be recycled in European facilities. Such recycling legislation requires that recyclable polymers be developed. In addition, that the location and formulations of resins must be standardized to make recycling cheaper.

Recycled plastics are being produced in waste streams much faster than they are being used in manufacturing. To help demand meet supply, the properties of recycled materials need to be better understood, the limitations addressed, and suitable manufacturing processes and markets developed.

\subsubsection{Technologies to Solve Problems}

Four general areas of technology development were identified by workshop participants:

- Materials Compatibility Studies - Materials compatibility issues dictate the feasibility of applications and manufacturing processes using recycled materials. For example, there is a need to understand how much virgin material must be added to a recycled plastic before it can be used again. It may even be possible to recycle plastics with other materials still intact (e.g., paint, adhesives, reinforcements) for certain applications, especially if reinforcements are added. In some cases, resins can be recycled only a 
specific number of times before they lose their integrity; therefore, data about aging are important. For these reasuns, the performance of recycled materials in actual applications must be understood before these materials can be marketed in products and processes requiring a high degree of reliability.

- Recycling Technology - Technology is needed to help the demand meet supply for products from used piastics and organic matrix composites. This includes manufacturing processes which allow recycled products to be mariufactured that are competitive or superior to products from virgin materials.

- Manufacturing Processes - Manufacturing processes for products from recycled materials (e.g., epoxies and polyamides) need to be demonstrated at federal facilities.

- Fundamental Studies - The goal of these studies should be to understand if materials compatibility can be improved as a result of manipulating molecular parameters.

\subsubsection{Next Actions}

Demonstrations are needed of applications of recycled plastics and associated manufacturing processes. NCMS and industry participants suggested that DOE support pilot-scale manufacturing facilities for materials such as ec vcled epoxies. The properties of recycled materials can be tested in prumising applications so that needed data on manufacturing processes can be made availabie to industry.

\subsection{SURFACE MODIFICATION}

Members of the surface modification working group included:

- Al Sylwester, SNL, leader

- Ron Roberts, General Motors

- Robert Reynolds, NCMS

- Mark Smith, SNL.

\subsubsection{Identification of Industry Problems}

Current industrial needs that require surface modification tecinology include: 
- Sensors - Sensor application needs include measurement of contaminants in products and waste streams, real-time monitoring and process control, measurement of movement and stresses in systems components, telemetry, and biomedical applications.

- Barrier Coatings - Coatings provide barriers to corrosion, mechanical wear, heat, ind erosion. Coating materials often have thermal expansion coefficients that are different than the underlying substrate, which results in locked-in stresses, cracking, and lack of adhesion upon cooling. Thin-film coatings are difficult to apply uniformly in high-production applications. Manufacturing processes are needed for coatings that minimize in-place stresses, increase uniformity, and minimize the production of secondary waste streams.

- Lubricating Films - Modified surfaces and new lubricants are needed that allow manufacturing equipment or other machinery to operate with no oil.

- Porous Surfaces - Surfaces with carefully controlled porous microstructures are needed for applications such as membranes, catalysts, and sensors.

- Metallization - Metallization is an important surface finishing process. Currently, plating operations result in excess acids and plating bath materials that contain contaminants such as nickel, chromium, cadmium, and zinc. As a result, metallization is a source of hazardous wastes for many industries.

\subsubsection{Technologies to Solve Problems}

Materials and processing capabilities needed to solve industry problems in surface modification include:

- Nondestructive Testing (NDT) Methods - NDT methods are needed to measure the thickness and hardness of thin films or coatings. NDT will ailow process and quality control to minimize internal stresses and increase uniformity.

- Process/Materials Modeling - Advances in computational capabilities hold promise for computer-assisted materials design (CAMD). CAMD is an emerging appraach that can minimize wastes and focus materials synthesis and processing efforts.

- Spray Coating Processes - The next generation of spray coating processes is needed. These processes should be continuous and demonstrate high control of the application rate, good adhesion, and limited carrier requirements. A promising technology at SNL is thermal spray coating for deposition of molten metal and carbide powders on a substrate. 
- Carbon Films - Thin carbon films are very promising for lubricating, corrosion resistant, and heat-rejection surfaces. New capabilities for low-temperature deposition of new forms of carbon (e.g., fullerenes) should be explored.

- Engineered Porous Materials - Engineered porous materials offer significant potential as membranes, catalysts, sensors, and barrier coatings. The porosity of materials is often dictated by control of the microstructure during growth conditions using innovative processing methods.

\subsubsection{Next Actions}

NCMS staff expressed considerable interest in several areas of AIM research in surface modification. They requested that additional information be made available about AIM programs. Opportunities should be explored for additional interaction between NCMS members and the DOE national laboratories conducting research in surface modification. Packages of information on $1 a b-$ oratory capabilities would be beneficial.

Sensors, membranes, thermal barriers, and spray coatings seemed to be the most promising areas for future collaboration. New areas recommended by NCMS that AIM should consider include developing thin films for microelectronic applications, conducting non-destructive evaluation of thin films, studying the thermal stability of coatings, and coupling the chemical response of sensor materials to actuators for improved characterization and fast mani. pulation of system parameters.

\subsection{CERAMICS, INTERMETALLICS, AND METALS (INCLUDING ALLOYS AND COMPOSITES)}

Working group members included:

- Peter Angelini, ORNL, co-leader

- Joseph Laia, LANL, co-leader

- Dan Maas, NCMS

- John Petrovic, LANL 


\subsubsection{Identification of Industry Problems}

Industry problems driving the development of new ceramic, metal, and intermetallic materials include:

- Need for Weight Reduction - Weight reduction is a primary concern in the transportation industry, because it is a means to achieve more stringent emissions and fuel-efficiency standards.

- Reduction in Scrap - Wastage of material during machining, cutting, and fabricating is a key concern for NCMS members. biastage results in higher product cost, the need for recycling and disposal of wasted stock, and the potential for generating metal slivers and cuttings that damage dies and other components.

- Need for Standards - Standard test procedures are needed for measuring materials properties as a function of processing and use.

- Recycling of Materials - Recycling of materials is being demanded by U.S. consumers. Legislation in Germany mandates recycling of automobiles and other consumer products.

\subsubsection{Technologies to Solve Problems}

The following technologies are listed in prioritized order:

- Materials Design and Manufacturing Process Design Methodologies About $80 \%$ of the cost of a system is incurred during the design stage. Concurrent engineering tools are needed 1) to allow design for the entire life cycle of the product (so that manufacturing, recycling, and other costs can be anticipated) and 2) to allow prediction of load and energy management performance in actual applications without extensive testing.

- Materials Property Data - Data on the properties of 1 ightweight materials are needed, so that component design using these materials is simplified. Materials of interest to NCMS members include metal-matrix composites, intermetallics, and heat-treatable steels. Properties of interest include cost; deterioration in service; and problems with machining, features manufacturing, casting, joining, and repair.

- Lightweight Materials - Safe, cost-effective methods are needed for synthesis and processing of metal-matrix composites, engineered plastics, and low-density materials (e.g., intermetallics). Currently, many of these materials cannot be cost-effectively manufactured into complex shapes and repair is difficult.

- Net Shape Manufacturing - Net shape manufacturing methods would allow many machining and stamping processes to be eliminated. 
These methods need to be continuous operations for the production of discrete parts in high-production operations. Materials of interest include plastics, aluminum, magnissium, and some castable metal-matrix composites.

\subsubsection{Next Actions}

NCMS staff should identify the engineered materials specification (e.g., formulations, types, shapes, components) of highest interest to their membership. This list can be made available to the DOE national laboratories so that they can tailor their capabilities to developing technology to manufacture to these specifications.

DOE should coordinate the capabilities of the DOE national laboratories and key universities in the areas of high interest to industry. Currently, it is difficult for industry to understand where the capabilities of the DOE national laboratories reside and to determine who is responsible for establishing programs to transfer existing research results to the private sector. DOE needs to categorize work to date, even if tangible results are not available. 


\subsection{CONCLUSIONS}

The ability to fabricate products from advanced materials using low-cost processes is critical to U.S. economic competitiveness. The research agenda at DOE AIM should include working with suppliers to develop manufacturing technology. The agenda should be driven by both energy conservation considerations and by industry needs. DOE should ensure that energy-efficient technology is wailable to meet these needs.

Problems of key concern to NCMS member companies include the:

- need for pilot-scale demonstrations of recycling processes for plastics and organic matrix composites

- need for materials with tailored surface properties for sensors and barrier coatings

- need for carefully controlled surface modification technologies that generate no waste

- need for manufacturing processes that do not generate scrap. Promising materials and processes to meet industry needs include:

- recyclable plastics, composites, carbon films, engineered porous materials, and low-density materials

- continuous processes for spray coating and net-shape forming

- sensors and NDT methods for quality control (e.g., measuring the thickness and hardness of coatings).

Materials development activities should be conducted in conjunction with materials compatibility studies, derivation of standards and materials property data, and the development of design tools. Building pilot-scale production facilities and evaluating new and recycled materials in federal facilities should be an essential part of DOE's research agenda in advanced materials.

Finally, active technology transfer through CRADAs and technical exchange with industry is encouraged. An important focus of the research 
should be to transfer the results of existing research into products and processes that are usable by the manufacturing industry. 
APPENDIX A

WORKSHOP PRESENTATIONS

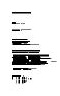


ADVANCED INDUSTRIAL CONCEPTS MATERIALS PROGRAM

OFFICE OF INDUSTRIAL PROCESSES

OFFICE OF INDUSTRIAL

TECHNOLOGIES

U.S. DEPARTMENT OF ENERGY

Dr. Charles Sorrell, Program Manager Advanced Industrial Materials Program Advanced Industrial Concepts Division U.S. Department of Energy

Mail Stop CE-232

1000 Independence Ave., SW

Washington, D.C. 20585

(202) 586-1514

(202) 586-7114, FAX 

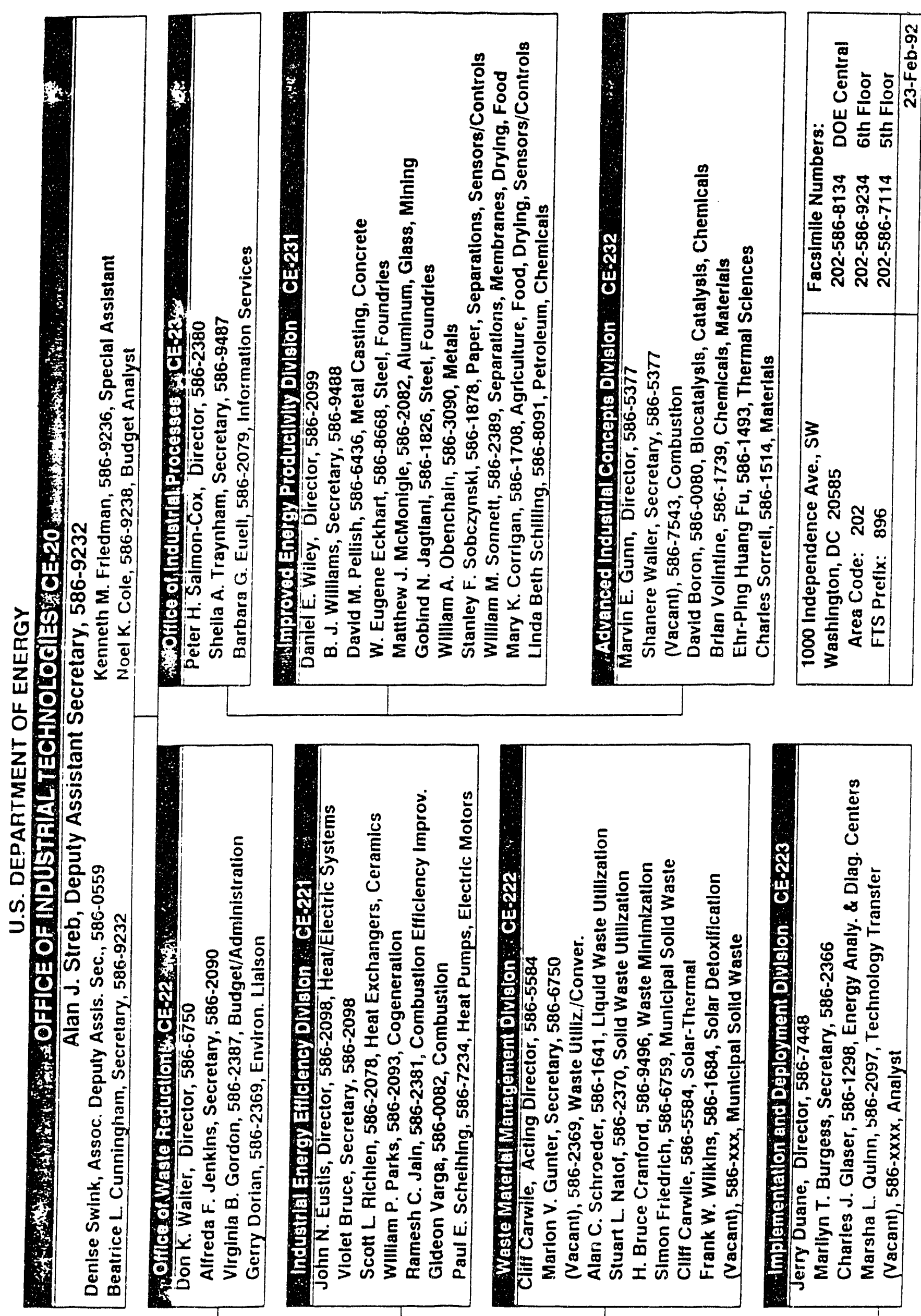

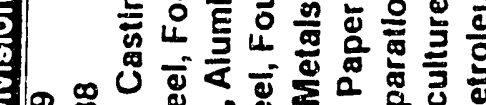
| ᄅ

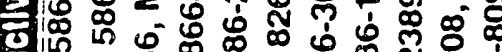
$8 \mid$\begin{tabular}{l}
0 \\
\hline
\end{tabular}

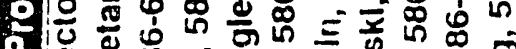
2.0 ㄴ.

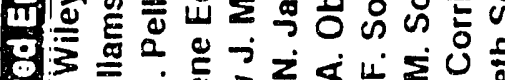
ठิ山

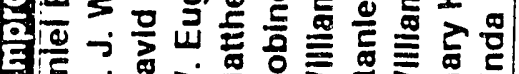
我

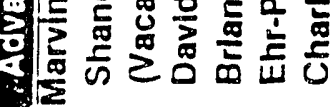
응
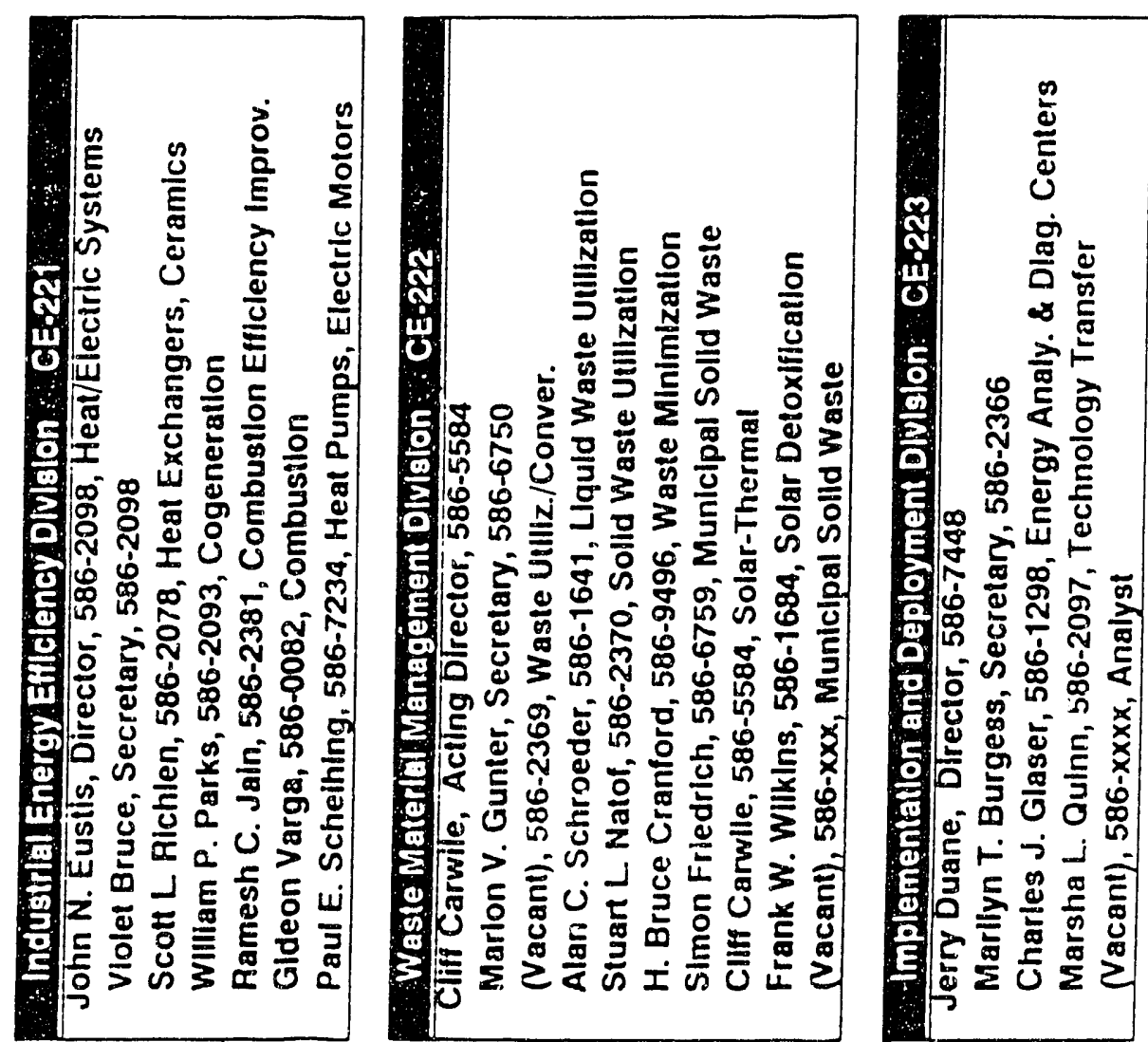

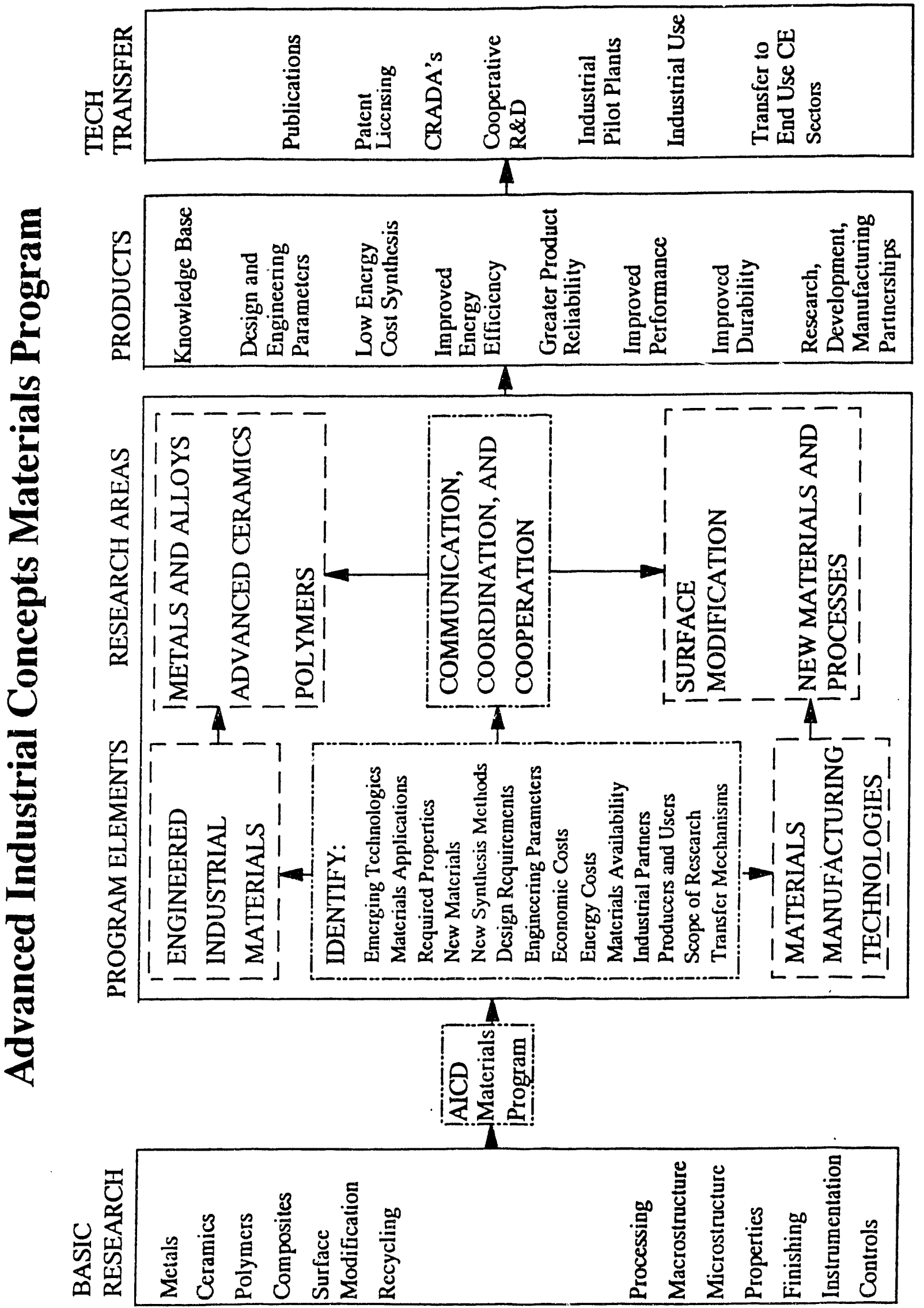


\section{MISSION}

- Conduct applied research and development to help bridge the gap between basic research and industrial application of energy saving materials and materials processing methods

- Develop materials that save energy by enabling improved system efficiencies and service lives

- Develop less energy intensive and less expensive materials processing methods using less expensive raw materials and fewer processing steps

- Serve as a resource for end-use programs and transfer work to those programs when appropriate

- Work with industry to identify materials needs, conduct cooperative research and development, and transfer technology to industry

\section{CERAMICS}

- Chemical Vapor Deposition of SiC - Sandia Livermore

- Chemical Vapor Infiltration of TiB2 - Oak Ridge

- X-Ray Tomography of Composites - Lawrence Livermore

- Microwave Spray Drying and CVI - Los Alamos

- Microwave Sintering of Oxides - Oak Ridge

- Aerosphere Ceramic Insulation - Georgia Tech

-Aerogel Insulation - Lawrence Berkeley 


\section{ADVANCED ALLOYS AND COMPOSITES}

- Ordered Intermetallic Alloys - Oak Ridge

- Intermetallic Alloy Composites - Los Alamos

-Rapidly Solidified Alloys - Idaho Nat'I. Eng. Lab.

\section{POLYMERS}

*Chemical Recycling of Plastics - NREL

- Polymers from Renewable Materials - NREL

- Magnetic Field Processing, Organic - Los Alamos

- Magnetic Field Processing, Inorganic - Idahc 


\section{SURFACE MODIFICATION}

- Conducting Thin Films - Los Alamos

- Surface Modification of Polymers - Oak Ridge

- Chemically Specific Thin Films - Sandia Albuquerque

- Biomimetic Coatings and Thin Films - Pacific Northwest

- Synergistic Coatings - Sandia Livermore and Magnaplate

\section{NEW MATERIALS AND PROCESSES}

- Multifunctional Foams and Membrane Materials - TBD

- Intermetallic Bonded Oxides and Carbides - Oak Ridge

- Composites by Metal Infiltration - Sandia Albuquerque 


\section{LINKAGES FOR PROGRAMMATIC FOCUS}

- Surface Modification

-. Protective Surfaces

-- New Coatings Development (SNLL, ORNL, Magnaplate, Rutgers)

-- Surface Treatment of Polymers (ORNL, LANL)

-. Magnetic Fieid Processing of Polymers (LANL)

- Biomimetic Processing (PNL)

-- Intermetallic Alloys (ORNL)

-. Functional Surfaces

-. Chemically Specific Surfaces (SNLA)

-. Biomimetic Processing (PNL)

\section{LINKAGES FOR PROGRAMMATIC FOCUS (cont'd)}

- New Materials and Processes

-- In Situ Formaion of Composites to Near Net Shape

-. Composites (Metal or Ceramic) by Reactive Metal Infiltration (SNLA)

- Molybdenum Disilicide Composites (LANL)

-. Bonded Oxide and Carbide Composites (ORNL)

-- X-Ray Tomography (LLNL)

-- Processing Modeling (ORNL, NIST)

- Fiber Reinforceu Coramic Composites

-. Titanium Diboride Composites (ORNL)

- Microwave Assisted CVI (LANL)

-. X-Ray Tomography (LLNL)

-- Processing Modeling (ORNL, NIST) 


\section{LINKAGES FOR PROGRAMMATIC FOCUS (cont'd)}

- Membrane Materials

- Aerogels (LBL, NIST)

-- Applications for insulation, filtration, catalysts, adiabatic demagnetization, ion exchange, batteries, sensors

-- Treatment of interior pore structure for chemically specific activity

-. Chemically Specific Surlaces (SNLA)

- Can be adapted as is or used to treat interior pores

-. SNLA has powerful computer modeling capability

\section{LINKAGES FOR PROGRAMMATIC FOCUS(cont'd)}

- Membrane Materials (contd)

-- Magnetic Field Processing of Inorganic Polymers (INEL)

.. Processing can change rates and selectivity

-- Conducting Polymer Thin Films (LANL)

-- Membrane characteristics can be tailored and altered in situ

-- Microwave Processing (LANL, ORNL)

- May have application for processing of sol-gels and CVI 
THE NCMS ADVANTAGE

John Sheridan

National Center for Manufacturing Sciences 900 Victors Way

Ann Arbor, MI 48108-1779

(313) 995-0300

(313) 995-4004, FAX 
NCMS

National Center for

Manufacturing Sciences

NCMS

The NCMS Advantage

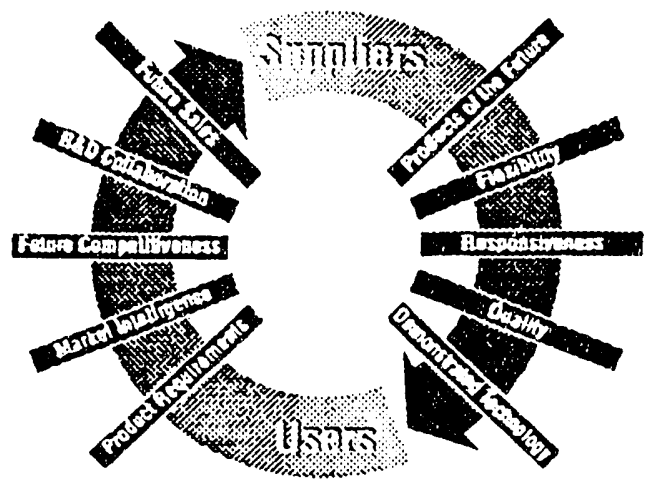

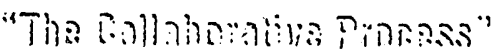




\section{Problem Statement}

- Manufacturing in North America is going downhill

- Technology is available in the marketplace - but technology is not being used or distributed effectively

- Need a mechanism to effectively transfer technology

- Need to make people aware of tecinnology

- Need to make available known technology

- Need to cffectively apply existing technology

- Necd to efficiently bring technology to readiness

- Need applicable technology development

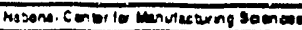

\section{Technology Adoption Time Frames}

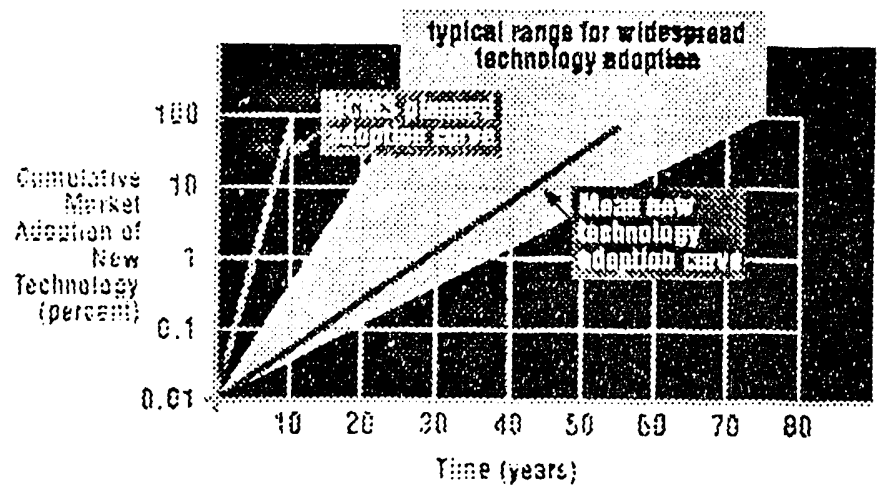




\section{NCMS Background}

- The National Center for Manufacturing Sciences is a not-for-profit cooperative research corporation.

- NCMS was organized under the National Cooperative Research Act of 1984.

- The purpose of NCMS is to fund research in manufacturing.

- NCMS will lead the effort to develop technologies and systems that will improve U.S. manufacturing processes and materials.

- The goal of NCMS is to see technologies implemented in its member companies.

- Achievement of World Class Manufacturing in a Clobal Peacetime Economy is our mission.

\section{NCMS Strategy}

- Through partnerships with industry and government - identify, support and field programs that increase competitiveness in American/Canadian manufacturing.

- Provide atmosphere for member company collaboration - thus increasing competitive leverage.

- Development of broad-based Technology Transfer Network for:

- New processes

- Underutilized processes

- Adaptation/enhancement of existing technologies 


\section{Selected Members}

AT\&T

Digital Equipment Corporation

Ford Motor Company

General Motors Corporation

The Gleason Works

GTE ?alenite Corporation
Hurco Companies, Inc.

Litton Industrial Automation Systems, Inc.

Measurex Automation Systems, Inc.

Rockwell International Corporation

Texas Instruments Incorporated

United Tecnnologies Corporation

Over 125 Member Companics

ACMTS

The NCMS Advantage

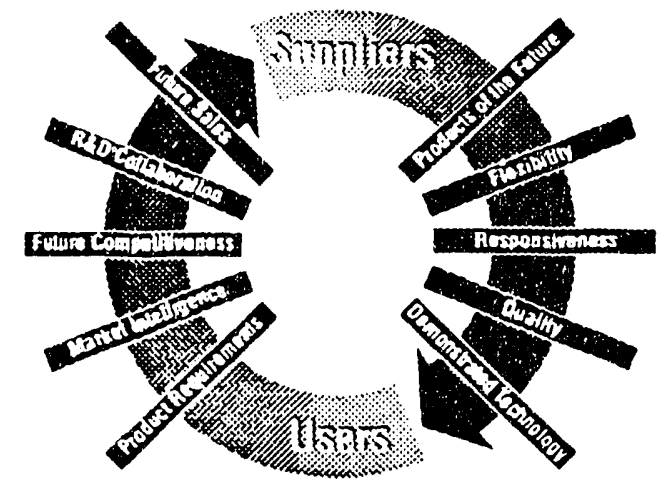

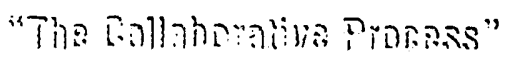

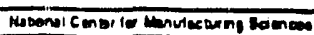

A. 13 


\section{Decreasing the cost of R\&D and operations}

- NCMS helps members benchmark against the competition.

- We offer significant leveraging of R\&D budgets.

- typical savings of $80 \%$

- We enable technology sharing, thereby reducing redundant $R \& D$.

\section{"Typical" Large Company Leverage}

"NCMS offers manufacturing companies a great opportunity

to leverage their manufacturing

$R E D$ investment. Il and its

NCMS partners are able to get

more "bang for their buck" by

pooling talent, RED

investrient, and equipment

in to projects solving common problems"

Lack E. Swindio

Sonior Vico Prosident

Toxas inztiumonts, Ine.

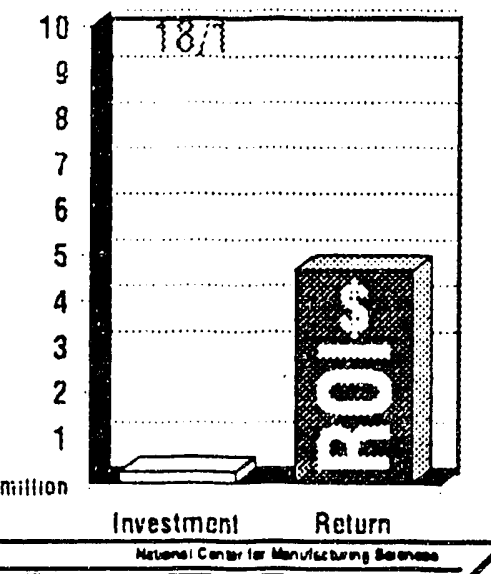

A. 14 


\section{"Typical" Small Company Leverage}

"NCMS prooides small companies like Kinefac

with unparalleled access to

the latest manu facturing

technology and a great

opportunity to join with

other large and small

companies alike in the

research needed to enhance

their competitiveness in

U.S. and world markets."

Howard A Gieis

Prosidenl

Kinabe Corporalion

Worcestar, Massachusatis

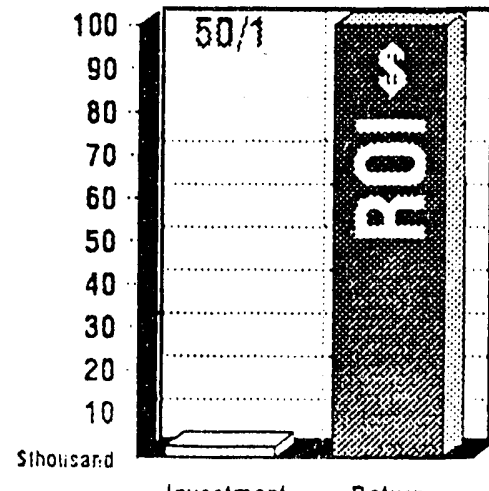

Investment Relurn

\section{Sechnology}
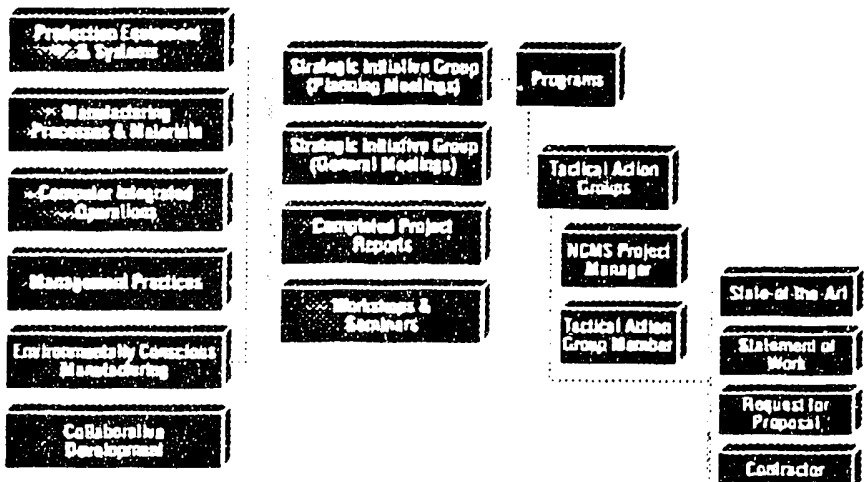

propidi:

Cocirido:

;

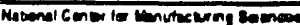




\section{Management Practices}

\section{Mission}

- To significantly improve North American manufacturing competitiveness in areas of:

- Quality

- Cost

- Delivery

- Fexibility

- Customer Satisfaction

- By forecasting, acquiring, generating, and deploying world-class manufacturing management practices

\section{Management Practices}

Programs

- Enterprise Management

- Achieving Manufacturing Excellence

- Benchmarking

- Human Resources

- Financial Policies

- Manufacturing Operations

- External Business Environment 


\section{Computer Integrated Operations}

\section{Mission}

- To monitor, analyze, research, develop and promote computer-based system integration technologies that enable an extended North American enterprise to operate and be competitive globally

\section{Computer Integrated Operations}

\section{Programs}

- Business Case for Computer Integrated Manufacturing

- Reference Models

- Integrated Support Program

- Beta Site Deployment 


\section{Manufacturing Processes and Materials}

\section{Mission}

- To significantly improve the capability of North American manufacturers to deliver high- quality cost-effective products in a dynamically evolving international marketplace by distinctive execution of four critical programs

\section{Manufacturing Processes and Materials}

\section{Programs}

- Advariced Proccssing Technologies

- Quick Prototyping

- Rapid Prototyping Technology Advancement

- Predictive Process Control

- Materials and Process Selection 


\section{Production Equipment and Systems}

\section{Mission}

- Advance the international competitive position of North American manufacturers

- Impact the national defense users, and machine tool builders' manufacturing bases for greater global competitiveness

\section{Production Equipment and Systems}

\section{Programs}

- Next Generation Controller

- Low End Controller

- High Productivity and Precision Machining

- Next Generation Inspection Systems

- Rapid Response Manufacturing 


\section{Environmentally Conscious Manufacturing}

\section{Mission}

- To establish and implement an advanced and innovative portfolio of science and technolugy $R \& D$ programs to ensure and facilitate environmentally conscious manufacturing

- To disseminate results to NCMS members, North American industry and academia

- To be the best source of environmentally conscious manufacturing science and technology

\section{Environmentally Conscious Manutacturing}

\section{Programs}

- Manufacturing Solvents \& Their Substitutes

- Remediation of Industrial Wastes

- Metal Working Fluids

- Emissions from Pointing Operations

- Reduced Lead Use in manufacturing

- Entissions from I'lating Operations

- Emerging Environmental Technologies

- Environmental Practices

- Life Cycle Design Environmental Compatibility

- Waste Minimization / Energy Conscrvation Interactions

- Sensors for Environmental Monitoring

- Bioplastics Initiative

- Appropriate Packaging Concepts 


\section{Collaboration (other members)}

- Printed Wiring Board Consortium (NIST ATP award)

- AT\&T, TI, UTC/Hamilton Standard, DEC, Sandia, NIST

- Rapid Response Manufacturing (NIST ATP proposal)

- GM, TI, UTC, Ford, Oak Ridge (Y-12), Aries, Cimplex, Cimflex Tecknowledge, ICAD, Parametric Tech., Spatial Tech.

- Sourcing from member laboratories

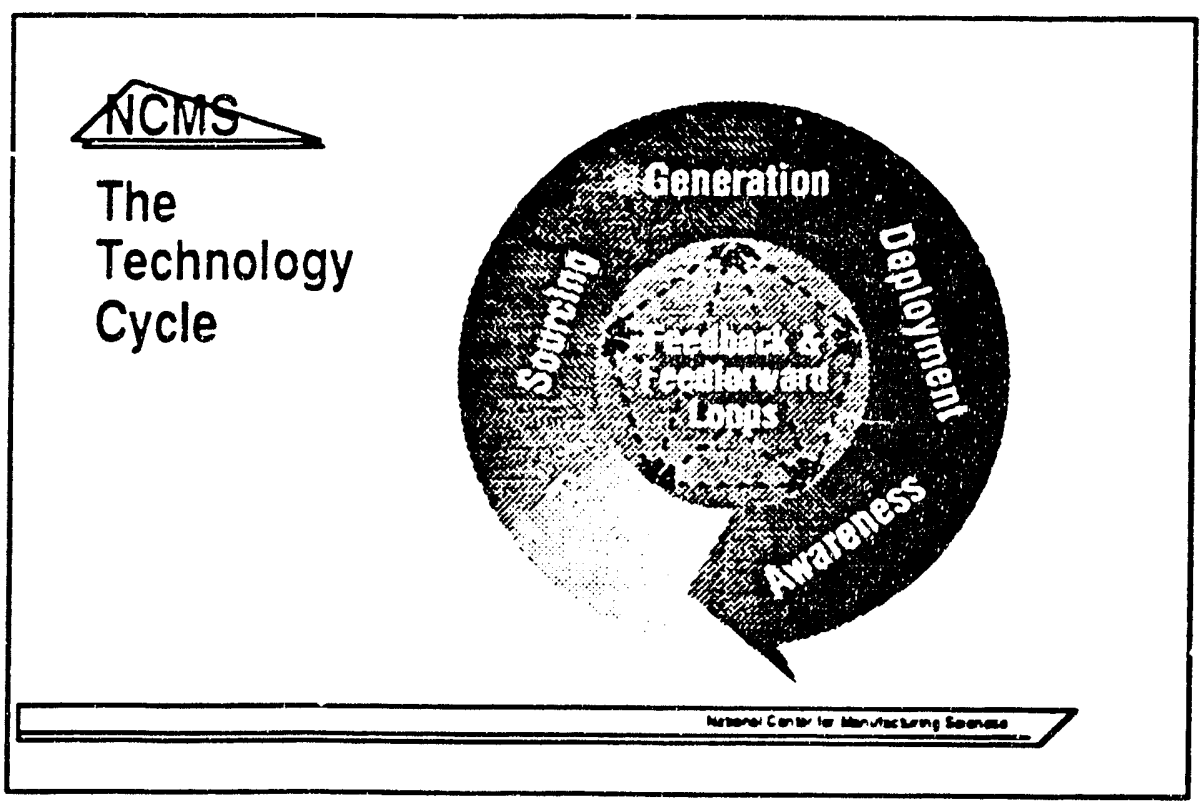




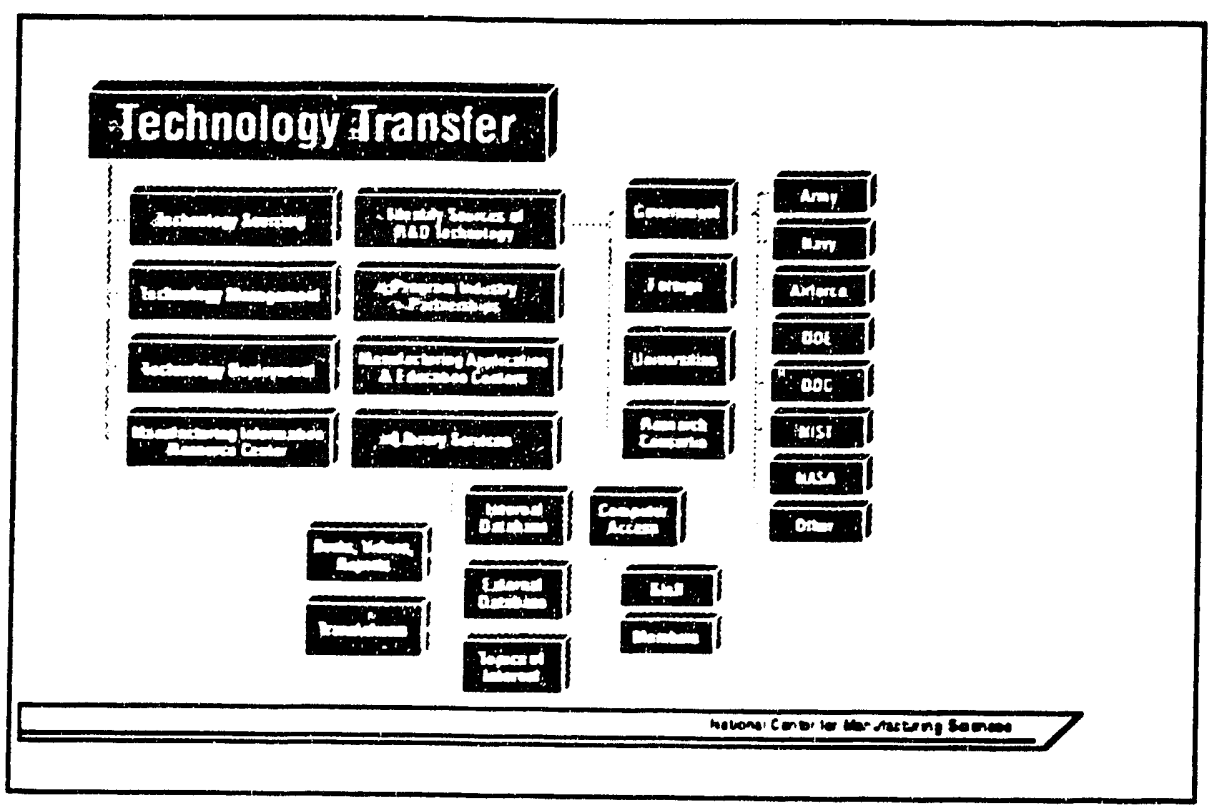

Sourcing Advanced Manufacturing Technology

Sourcing and deploying advanced manufacturing technology from

- Government labs and production facilities

- Global sources

- Member companies

- Universities

- Other consortia and related research organizations 
Sourcing Advanced Manufacturing Technology

\section{Developing a pull approach}

- Seeking technology that will support current or planned R\&D programs

- Identifying members' technology needs/opportunities

- Identifying technologies that can improve competitiveness of members

Sourcing Advanced Manufacturing Technology

Developing general memoranda of understanding and cooperative research and development agreements to expedite the sourcing process

- Standard terms and conditions.covered in generic MOUs and CRADAs

- Individual project agreements can be developed rapidly under generic MOUs and CRADAs 


\section{Sourcing Advanced Manufacturing Technology}

\section{MOUs and CRADAs in place with:}

- Dept. of Energy - Generic CRADA to be signed

- Watervliet Arsenal / Benet Labs - Generic CRADA

- Environmental Protection Agency - Generic CRADA

- Microelectronics and Computer Consortium - MOU

- Others in Process:

- NASA

- Navy

- Air Force

-. There are 14 scoarale existing NCXIS technica! propcis awalung the signing of the DOE CRADA

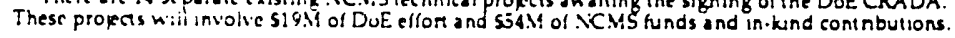

Sourcing Advanced Manufacluring Technology

CRADA Activity at Watervliet Arsenal / Benet Labs:

- Manufacturing Processes \& Materials:

- Total Productive Maintenance / Tool Monitoring

- Waterjet cutting

- Environmentally Conscious

Manufacturing:

- Metal Working Fluids

- Plating Fluids

- Replacing Volatiles in Coatings 


\section{Global Sources}

- Importing Ukrainian

Technologies

- Liaison Technologists in

Europe and Asia

\section{Global Sources}

Importing Ukrainian Technologies

Candidate Technologies

- Paton Institute

- Electron Bcam Physical Vapor Deposition of Carbide Coatings

- Electron Beam Mclting of Metals (Ti, Ni-superalloys)

- Gyrotron Microwave Processing for Coatings

- Thermal Barrier Coatings

- Dnepropetrov'sk Metallurgical Institute

- Ductile White (Cast) Iron

- Anisotropic Porous Matcrials

- TEMP Electronic Factory

- Thick Film Pastes for Circuit Boards

- Soldering Metal to Class 
Sourcing Advanced Manufacturing Technology

\section{Ukrainian Materials Technologies}

- Six original technology areas expanded to eight TAG projects.

- Electron Beam (EB) Carbides and Diamond-like coatings,

- EB fiber coatings,

- EB Thermal Barrier Coatings,

- Gyrotron Processing of Electron Circuit Boards,

- Microlaminates,

- Anisotropic Porous Materials,

- PICT Cast Iron,

- Diamond Honing

Three projects starred

Sourcing Advanced Manufacturing Technology

\section{Ukrainian Materials Technologies}

- ONR will fund 2Q92 travel of Soviet scientists to US for additional workshops, as well as partial funding for technical samples.

- Second Ukraine trip conducted $1 / 27-2 / 7 / 92$.

- Gorky gyrotron completed and ready to ship to Los Alamos National Lab for use by industry and laboratory persormel. 


\section{PICT - Iron}

- Plasticity Induced Carbide Transformation

- New composition and process

- But conventional mill equipment

- Low cost

- High hardness - 62 to $68 \mathrm{Rc}$

- Wear resistant

- Improved toughness

\section{Cooperation with Other Consortia}

\section{National Issues}

- Establish industry-driven manufacturing vision, metrics, common process

- Establish master Manufacturing R\&D agenda

- Deal with barricrs to cooperation

- Create interplay betw'een standards committees and R\&D groups

- Develop the business case for manufacturing modernization

- Address issues relevant to small companics 


\section{Cooperation with Other Consortia}

- ClO project, "A Business Case for CIE" developed linkages to CAM-I program " CIE Guidelines and Methodologies".

- NCMS joined the MCC project "Enterprise Integration Net" with the intent of using that network as an electronic communications vehicle between NCMS, its members, other networks and between members.

- EPRI considering providing additional funding for selected MP\&N programs

- Discussing similar interest from GRI

- New start March '92

- Effort to source member-owned technologies that members decide not to implement in their own strategic plans.

- Plan NCMS "garage show(s)" in summer/fall, inviting labs which have generic CRADA. 
Managing the Technology Deployment Process

Building deployment and commercialization capabilities into the project team

- Both users and suppliers of the technology included on member project team provides built in pull

- An organization capable of taking the technology to market must be included in the contract team

Managing the Technology Deployment Process

\section{Building Technology Deployment into the} Technology Development Programs

- NCMS Technology Transfer staff participates in SIG technology planning process

- Technology Transfer and Deployment requirements specified in all project agreements/contracts 


\section{Technology Deployment}

\section{Manufacturing Application \& Education Network}

- The Manufacturing Application and Education Network (MAEN) made up of Manufacturing Application and Education Centers (MAEC)

- They will be analogous to the teaching hospital

- It will bring together all the necessary functions needed for manufacturing improvement in one place

\section{Strategic Model}

How the NCMS strategy will work

- NCMS contracts mariagement and operation

- NCMS works as a partner

- NCMS representative at cach conter

- NCMS responsible to help identify optimum approaches

- N'CMS programs will be deployed througth the Centers 


\section{Each MAEC to be a Business in Itself}

- The purpe of each center to include the following:

- Train users within an operational and hands-on environment

- Educate users in applications

- Demonstrate current and potential SOA technology and best practices

- Harden technology in a production environment

- Validate technology for specific applications

- Advance applicabic icchnology through continuous improvement

- Produce parts

- Develop formal degreed program

\section{Short History of the MAEN}

- Started with the idea of 20 facilitics - now thinking 150 or more

- Want to reach a mavimum number of firms

- Practical limit of about a 100 mile radius of service

- Belicve organizations are available for number required

- Studies identificd about 30 major economic centers and 55 major industries

- Believe that financing is available to support the idea

- Working on legislation to help MAEN concept

- Working a coalition of groups to further support this initiative 


\section{Why the Time is Now for MAEC}

- We have all the successful ingredients for MAEC in the U.S. today

- Good model educational systems at all levels

- Operating demonstration facilities

- Well developed business systems

- Accessible production facilities

- Great opportunity for staffing manpower

- Good equipment

- Excellent R\&D facilitics and personnel

- No One has Brought the Pieces Together ..

THIS IS OLR TASK!

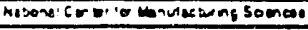

\section{Building the Manufacturing Information Resource Center}

- NCMS has created a unique Information Resource Center focused exclusively on manufacturing and manufacturing technology

- The Manufacturing Information Resource Center provides the following services:

- Library Services to members, staff and rescarch contractors offering a collection of more than 11000 documents, audio/visual matcrials and software focused on manufacturing and manufacturing technology

- Research Services to members, staff and rescarch contractors with on-line access to more than 400 technical and business databases via 17 scrvices. 


\section{Manufacturing Information Resource Center}

(continued)

- Publication and Distribution of NCMS technical reports

- Access to the NCMS TRACK on-line full text database on manufacturing and manufacturing technology

- Global information sourcing and translation services

NCMS - From Concepts to Member

Companies Utilization for Profits
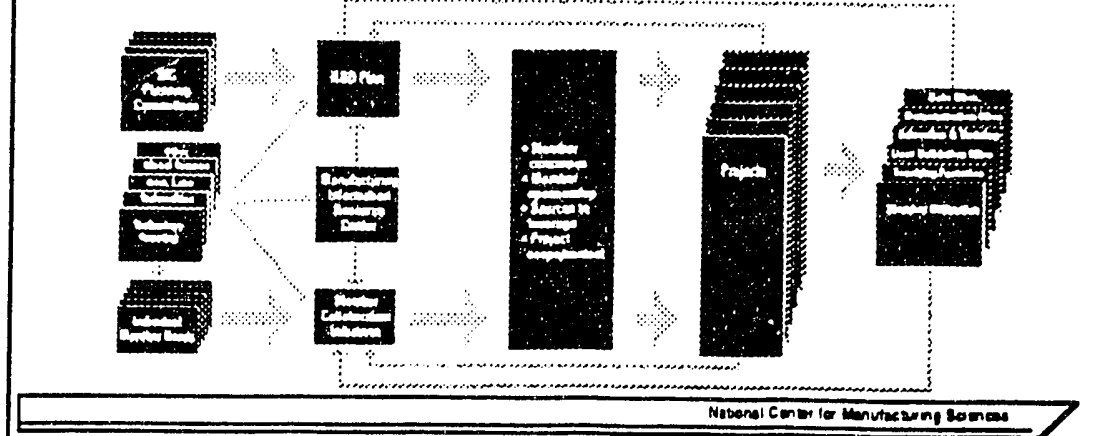

. 


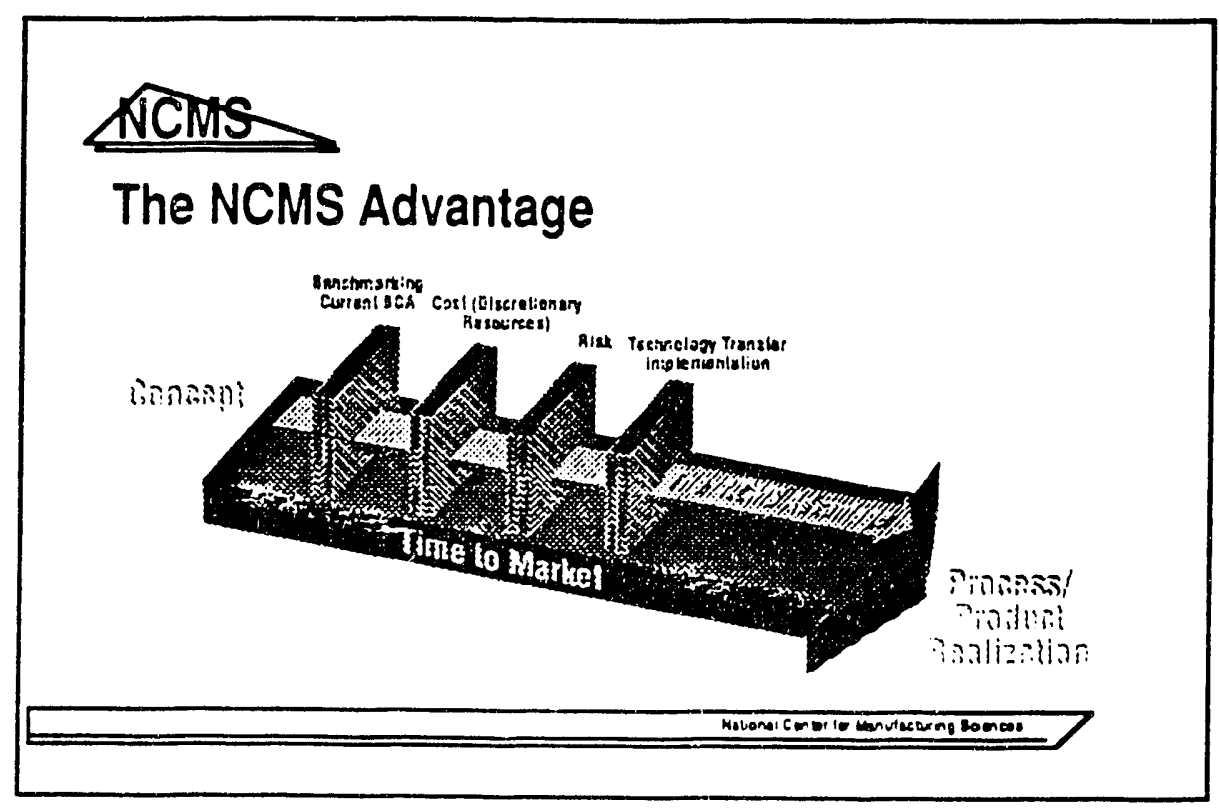

A. 34 
Sourcing Advanced Manufacturing Tochnology

NCMS - DOE Generic CRADA

Approach

- Flat Management Structure to Promote DOE/LAB Teamwork

- Single Infrastructure for Consistency

- Need to leverage Limited Human Resources

- Delegate Authority for Speed

- "Up Fror.t" Industry Involvement

Sourcing Advanced Manufacturing Technology

NCMS - DOE Generic CRADA

DOE Management Structure
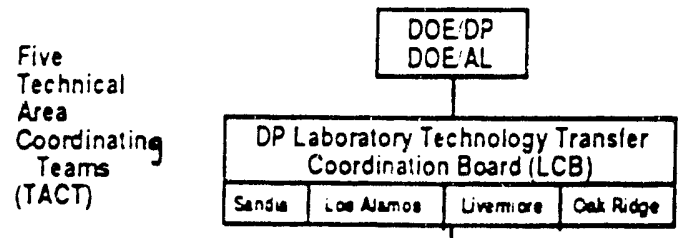

\begin{tabular}{|c|c|}
\hline Lnemere & Sent:a \\
\hline $\begin{array}{l}\text { Piecision } \\
\text { Enginee ing } \\
\text { Aovenes o } \\
\text { Wlanulaseuting }\end{array}$ & 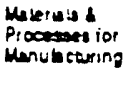 \\
\hline Industry 5 and & Incusty Band \\
\hline NCHS PEGS & NEUS MFGH \\
\hline
\end{tabular}

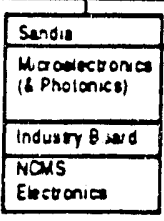


Sourcing Advanced Manufacturing Technology

NCMS - DOE Generlc CRADA

Why LCB/TACTs?

- Consistency

- Promote Teamwork

- Provide Infrastructure

- Speed

- "Best Ball"

- Bridge the Gap

Sourcing Advanced Manufacturing Technology

NCMS - DOE Generic CRADA

Bridging the Gap

Phase 1

Phase II

Phase III

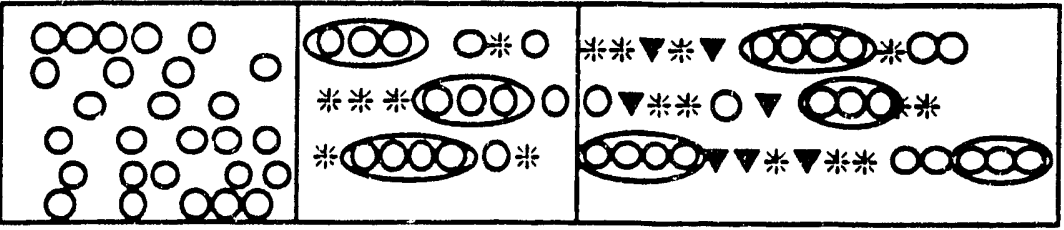

7000 Flowers Bloom

"Chsters"

Major Program Initialive

O Individual CRADAs

- Toch. Areas

- National Lovel impace

$\checkmark$ Industry Consontia

- By Sector

"Leap Frog" Advances in

* Major Progrom

Enabling Toch. Areas

Intitatives

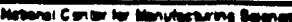

A. 36 
Sourcing Advanced Manufacturing Tuchnology

NCMS - DOE Generic CRADA

\section{Roles and Responsibilities of DOE} Detense Programs

- Overall Technology Commercialization Initiative (TCl)

- Final approval authority for all activities

- Provide high level guidance to DP Technology Transfer Coordinating Board

- Long Term Strategic Manning and Program Direction

- Budget Alloca ion

- Participate in Program Development, New Initiatives, etc.

- Interface between $\mathrm{TCl}$, other government organizations and program sponsors

- Knowledge of Industries needs, wants and problems with the process

Sourcing Advanced Manufacturing Technology

NCMS - DOE Generic CRADA

Roles and Responsibilities of DOE/AL and DOE Area Offices

- Participate in Strategic Program Direction Activities

- Approval Authority for Joint Work Statements (JWS)/CRADAs

- Budget oversight

- Provide progress reports

Respond to DOE/DP Information requests

- Interface with laboratory budget officc

- Interface with laboratory Tech Transfer Office

- Proactively Facilitate CRADA Processes. 
Sourcing Advanced Manufacturing Technology NCMS - DOE Generic CRADA

\section{Roles and Responsibilities of Laboratory Coordinating Board}

- Serve as the Single DOE/DP Infrastructure for TCl

- Recommend Program Funding Requests

- Develop Business Terms and Conditions

- Management of TACT' Activities to include:

- Oversight of Proposal Review Process

- Recommendations for Approval of TACT Strategic Plans

- Facilitate Inter-TACT Coordination

- Funding Recommendations for Technical Areas

- The CB is to provide an Ombudsman's role

Sourcing Advanced Manufacturing Technology

NCMS - DOE Generic CRADA

\section{Roles and Responsibilities of Technology Area Coordinating Teams}

- Manage existing Technology' Transfer Portfolios in Technology Areas

- Identify "Clusters"

- By Technology Areas

- Multiple Partners

- Work with Industry Advisors to Identify and Develop

Recornmendations for Major Program Initiatives

- Develop and Coordinate Strategic Plans with Industry for Technology areas

- Manage Proposal Development and Selection (e.g., call, review,

prioritize, rank, recommend, review, etc.)

- Conduct Project Reviews Quarterly

- Adjust Strategic Plans

- Provide Capabilities Assessments of DP Complex 


\section{NCMS ENVIRONMENTALLY CONSCIOUS MANUFACTURING}

Don Walukas

National Center for Manufacturing Sciences 900 Victors Way

Ann Arbor, MI 48108-1779

(313) 995-0300

(313) 995-4004, FAX 


\section{NCMS Environmentally Conscious Manufacturing}

\section{Initiated Programs/Projects}

- Manufacturing Solvents and Their Substitutes

- Environmental Impact Assessment of Alternative Solvents

- Environmental Impact Assessment Monitoring \& Modeling

- Material Compatibility Issues in Electronic Components

- Electronic Component Compatibility Testing

- Definition \& Measurement of Clean Electronic Components

- Solventless Cleaning of Electronic Components

- Definition \& Measurement of Clean Cut Metal Parts

- Definition \& Measurement of Clean Composites

\section{NCMS Environmentally Conscious Manufacturing}

1991 Initiated Programs/Projects (continued)

- Remediation Of Industrial Wastes

- Assessment of Bioremediation Applications

- Advanced In-Situ Bioremediation Developments

- Emissions from Surface Finishing Operations

- Advianced Methods of Paint Application

- Assessment of Plating Emissions Control Technology

- Handling and Disposal of Metal Working Fluids

- Machine Tol Design Optimization for Metal Working Fuid Use

- Reduced Lead Use in Manufacturing

- Advanced Mechanical Interconnects in Electronic Components 
Environmentally Conscious Manufacturing

\section{Manufacturing Solvents \& Their Substitutes}

Material Compatibility Electronic Components

Purpose:

To understand the compatibility of various materials used in

electronic assemblies with potential Ozone Depleting Chemicals

(ODC) alternatives, prior to implementing them within assembly processes.

Participants:

Texas Instruments (Lead); United Technologies Hamilton Standard

and Norden; AT\& T; General Motors Delco and Hughes; Ford.

Status:

Solvents \& Materials Selected

Testing Protocol Approved (IPC considering for standard)

Work Distribution Agreed Upon

Testing Initiated

Wroons i coner to tenutecturng someal

Environmentally Conscious Manufacturing

\section{Manufacturing Solvents \& Their Substitutes}

Material Compatibility Electronic Components

Materials:

Metals

Platings and Conversion Coatings

Polymers

Composites

Elastomers

Adhesives

Non-Metallic Coatings

General Marking Materials

Miscellaneous Materials
Solvents:

Freon TMS (Control)

1,1,1 Trichloroethane (Control)

HCFC Vertrel 245

Terpene Bioact EC-7R

Terpene Petroferm/Alpha

Isopropyl Alcohol

High Boiling Alcohol lonox $\mathrm{HC}$

Organic Blend EC-5 Petroferm

Reactive Aqueous Defluxing System 
Environmentally Consclous Manufacturing

\section{Existing Programs - New 1992 Projects}

- Manufacturing Solvents \& Their Substitutes

- Solvent Alternatives Hand Wiping Applications

- Environmental Compatible Processes for Non-Destructive Testing Cut Metal Parts

- Assessment of Aqueous Cleaning Equipment Cut Metal Parts

- Vapor Degreasing Equipment Alternatives Cut Metal Parts

- Solvent Waste Minimization Electronic Components

- Advanced Cleaning Equipment Electronic Components

Environmentally Conscious Manufacturing

\section{Existing Programs - New 1992 Projects (contirued)}

- Emissions from Surface Finishing Operations

- Low VOC Production Paints

- Environmentally Compatible Plating Processes Aerospace Applications

- Conformal Coating Characterization Electronic Components

- Chromate Bath Life Optimization

- Remediation of Industrial Sites

- Sand Binders in Foundry Wastes

- Assessment of Methods for PCB Remediation

- Reduced Lead Use in Manufacturing

- Lead Free Solders

- Alternatives for Fixturing Alloys 
Environmentaily Conscious Manufacturing

New 1992 Programs

- Environmental Practices

- Risk Assessment Methods

- Manufacturing Application \& Education Center Implementation

- Strategic Developments

- Environmental Management Practices

- Formal Technology Sharing

- Pollution Prevention Program Development

- Sensors for ECM Processes

- Assessment of Sensor Needs in ECM

- Life Cycle Design for Environmental Compatibility

- Assessment of Current Practioes and Trends

- Concept Implernentation

- ELM Packaging Initiative

- Packaging Minimization

- Waste Minimization \Energy Conservation Practices

\section{Environmentally Conscious Manufacturing}

\section{Summary}

- The Environmental Issues in Manufacturing Conference summarized the NCMS member coincidental activites and initiated the planning for collaborative and cofunded activities in the environmental area

- A new initiative directed toward Environmentally Conscious Manufacturing is established and the planning includes collaborative and cooperative partners 


\section{NCMS PRODUCTION EQUIPMENT AND SYSTEMS SIG. \\ 1992 PROGRAM/PROJECT LISTING}

Nick Weil

National Center for Manufacturing Sciences 900 Victors Way

Ann Arbor, MI 48108-1779

(313) $995-0300$

(313) 995-4004, FAX 


\section{ADVANCED MACHINING TECHNOLOGY INITIATIVES (AMTI) PROGRAM}

Defined Projects:

- Advanced Vertical Grinder

- Adaptive Controls for Turning Centers

- Real Time Error Correction for Piston Turning Machines

Planned Projects:

- Light-Weight, High-Power Spindles

- Innovative Spindle Concepts

- Structural Characterization of Machine Tools

\section{PRODUCTION SYSTEM METROLOGY (PSM) PROGRAM}

Defined Project:

- Next Generation Inspection System (NGIS)

Planned Project:

- Optical Gaging! 


\section{MACHINE TOOL ACCURACY INITIATIVES MTAI) PROGRAM}

Defined Projects:

- Machine Tool Accuracy Procedures

- Volumetric Accuracy Software Tools

- International Standards Evaluation

- Technology Transfer

Planned Project:

- Machine Tool Accuracy Benchmarking

\section{RELIABILITY AND MAINTAINABILITY (R\&M) PROGRAM}

Defined Projects:

- Reliability and Maintainability Guidelines

- Total Productive Maintenance 


\section{MANUFACTURING PROCESSES AND MATERIALS 1992 PROJECTS}

Dan Maas

National Center for Manufacturing Sciences 900 Victors Way

Ann Arbor, MI 48108-1779

(313) 995-0300

(313) 995-4004, FAX 


\section{MANUFACTURING PROCESSES AND MATERIALS - 1992 PROJECTS March 16, 1992}

- Waterjet and Abrasive Waterjet Machining - Phase 1

- Automatic Inspection System for Surface and Edge Finishing

- Distributed Laser Processing System

- Diamond Film Phase Ib

- Cure Sensor Systems for Composite Materials

- Advanced Tools and Methods for Machining Non-Homogeneous Materials

- ECM Process Control

- Joining of Composites and Dissimilar Materials

- Adaptive Process Control of Compression Molded Composites

\section{MANUFACTURING PROCESSES AND MATERIALS - 1992 PROJECTS (cont'd) March 16, 1992}

- Rapid Prototyping Technology Advancement - Thermal Spray Coatings Technology Advancement

- Low Pressure Direct Suspension Waterjet Process Development

- Predictive Model and Methodology for Heat Treatment Distortion

- Thixomolding Engineering Database for Magnesium 


\section{EXPERIENCES FROM THE FRONT LINE}

David R. Andres

Manager, Advanced Purchasing General Motors Corporation Saginaw Division 3900 Holland Road Saginaw, MI 48601-9494 (517) 757-4080

(517) 757-4044, FAX 


\section{MAJOR EVENTS}

- GM Scouting Missions

- November, 1991 Saginaw Conference

- Ongoing Series of Technical Discussions and Visits

- January, 1992 GM "Garage" Show

- August, 1992 Manufacturing Technology Exposition

\section{NOVEMBER, 1991 SAGINAW CONFERENCE}

"Saginaw Developed/Circulated One Page "Needs" Abstracts

- Labs Identified Areas of Interest and Capability

- Strong Matches Formed Conference Agenda

- 42 Abstracts Presented

Results

2 CRADA's in Place

5 More CRADA's in Final Negotiations

20 More Folded into Mega Projects

\section{A. 50}




\section{SAGINAW - OAK RIDGE CRADA}

- First GM/DOE CRADA - Signed February 4, 1992

- 2 1/2 Year Project

- Develop Improved, Longer Life Assemblies for Heat Treat Furnaces

- Apply Proprietary Nickel Aluminide Materials Developed by Oak Ridge

- Expect 3X - 4X Life Improvement of Assemblies

\section{WHY UTILIZE GOVERNMENT LABS?}

1. To Address GM's Technology Needs

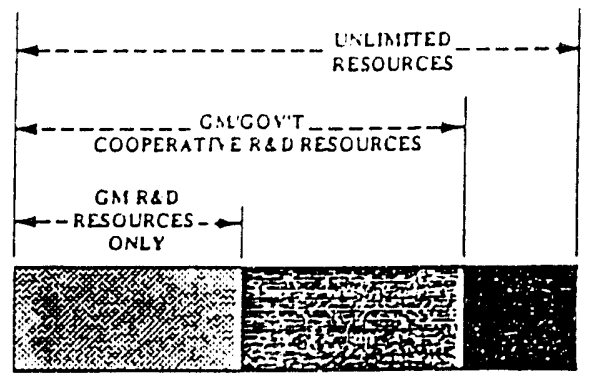

GM'S CURRENT TECHNOLOCY NEEDS 
WHY UTILIZE GOVERNMENT LABS? (((cont'd)

2. To Access a Wealth of Expertise and Capability

- Approximate yearly non-defense R\&D budget for Federal laboratories $=\$ 20,000,000,000$

-100,000 federal engineers and scientists

-U.S. industry must learn how to supplement in-house R\&D

\section{WHY UTILIZE GOVERNMENT LABS? (cont'd)}

3. To Compete in the New Paradigm

Simply Put... One Company Cannot Compete Against Several Countries

- Governm:cit Perspectives:

- Focus shift from military to economic

- U.S. won cold war but losing economic war

- Military challenges similar to industry (quality, cost, lead time, and technology acceleration)

- Supplier base competence and competitiveness an issue

- Industry Perspectives:

- Too expensive to engage in redundant research (especially to fulfill broad social needs)

- Need to level international playing field through synergistic cooperation

- Supplier base competence and competitiveness an issue 


\section{SAGINAW DIVISION APPROACH}

- Load Internal Resources into Areas of Core Competency

- Leverage External Resources in All Other Areas

- Know Your Needs

-Work From Your Home Base

- Networkl--It's a Contact Sport

\section{GEARING UP!}

A Manufacturing Forum for Getting Comperitive, Staying Competitive

The Ryder Center

Saginaw Valley State University

Saginaw, Michigan

August 24-26, 1992

Dinner \& Open House

August 24, 1992

Invited Key Note Speaker:

Governor John C. Engler

Exposition

August 25-26, 1992 


\section{GEARING UP!}

A Manufacturing Forum for Getting Competitive, Staying Competitive

\section{Sponsors}

Saginaw Division, General Motors

The Dow Chemical Company

National Center for Manufacturing Sciences

National Institute of Standards and Technology

State of Michigan Department of Commerce

Michigan Manufacturer's Association

Saginaw Valley Manufacturer's Association

Saginaw Valley State University

GMI Engineering \& Management Institute

Invited: Dow Corning Company

Whirlpool Corporation

\section{GEARING UP!}

\section{A Manufacturing Forum for Getting Competitive, Staying Competitive}

\section{Purpose}

A manufacturing forum for the 1990's and beyond. We're inviting thousands of small and medium size manufacturers and trying to bring Federal, State, and local manufacturing technology expertise directly to people who can make change happen!

The focus is pragmatic, hands-on advice, technology, and techniques. 


\section{GEARING UP!}

A Manufacturing Forum for Getting Competitive, Staying Competitive

\section{Audience}

CEO's

Presidents

Plant Managers

Manufacturing Managers

Engineering Managers

R\&D Managers

manufacturing Engineers

of small and medium size manufacturing firms

\section{GEARING UP!}

A Manufacturing Forum for Getting Competitive, Staying Competitive

Exposition Groupings

1. Improving Current Processes

2. Applying Available Technologies

3. Integrating Advanced Technologies

4. Accessing the Resources 


\title{
GEARING UP!
}

\author{
A Manufacturing Forum for Getting Competitive, \\ Staying Competitive
}

The event is non-profit and will be funded from a $\$ 35$ admission fee

Participants are asked to accept responsibility for their own personnel, lodging, travel, food, and exhibit costs

\section{GEARING UP!}

A Manufacturing Forum for Getting Competitive,Staying Competitive

Participants: Argonne National Laboratory

Federal Laboratory Consortium

Idaho National Engineering Laboratory

Lawrence Livermore National Laboratory

Los Alamos National Laboratory

NASA Regional Technology Transfer Centers

National Center for Manufacturing Sciences

National Institute of Standards and Technology

Regional Manufacturing Technology Centers

Shop of the 90s

National Technology Transfer Center

Oak Ridge National Laboratory

Pacific Northwest Laboratories

Sandia National Laboratory

Wright Laboratory - Wright-Patterson AFB 


\section{GEARING UP!}

A Manufacturing Forum for Getting Competitive,Staying Competitive

Participants: State of Michigan Department of Commerce MERRA

Michigan Manufacturing Technology Association

Saginaw Valley State University

GMI Engineering and Management Institute

GM Knowledge Center

GM EDS

GM Value Management Committee

Society of American Value Engineers

Regional Skills Development Network

Bay City Growth Alliance, Inc.

Midland County Erowth Council

Saginaw Future, Inc.

\section{GEARING UP!}

\section{A Manufacturing Forum for Getting Competitive,}

Staying Competitive

\section{Participants}

We are continuing to identify and invite laboratories, agencies, universities, and any other organizations who have talents applicable to the target audience. 
APPENDIX B

LIST OF ATTENDEES 
APPENDIX B

\section{LIST OF ATTENDEES}

Government/Industry Workshop on

New Materials and Processing Technologies

For Industrial Applications

Apri1 15, 1992

James E. Anderson

Principal Research Scientist

Ford Motor Company

Scientific Research Laboratory

21500 Oakwood Blvd.

Mail Stop 530-83

P.0. Box 2053

Dearborn, MI 48121-2053

David R. Andres

Manager, Advanced Purchasing

General Motors Corporation

Saginaw Division

3900 Holl and Road

Saginaw, MI 48601-9494

(517) 757-4080

(517) 757-4044, FAX

Peter Angelini

Oak Ridge National Laboratory

P.0. Box 2008

Building 4515

Mailstop 6065

Oak Ridge, TN 37831-6065

(615) $574-4565$

(615) 574-6098, FAX

Kerry J. Barnett

National Center for Manufacturing Sciences

900 Victors Way

Ann Arbor, MI 48108-1779

(313) 995-0300

(313) $995-4004, F A X$

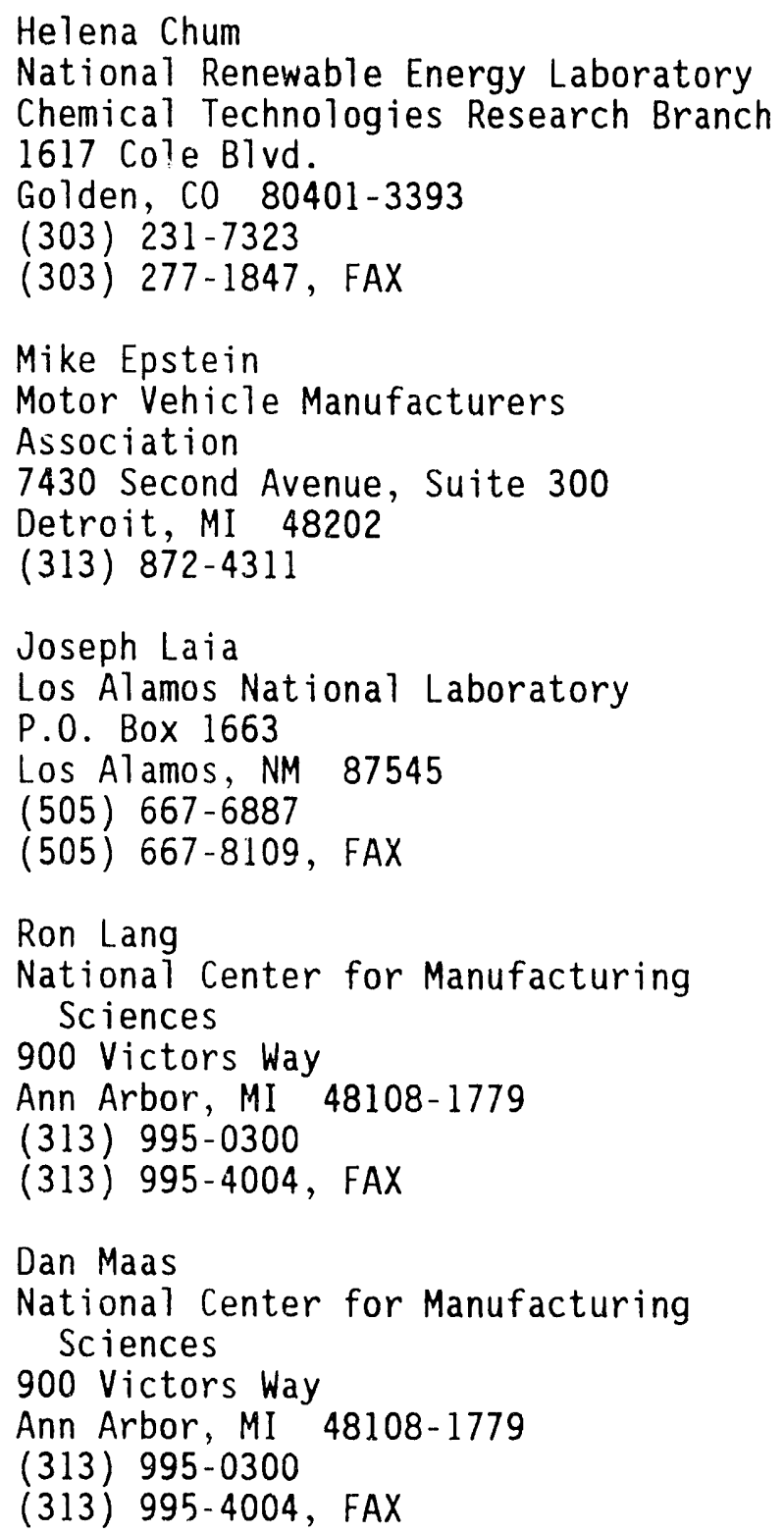

Helena Chum

Chemical Technologies Research Branch 1617 Cole Blvd.

Golden, CO 80401-3393

(303) 231-7323

(303) 277-1847, FAX

Mike Epstein

Motor Vehicle Manufacturers

Association

7430 Second Avenue, Suite 300

(313) $872-4311$

Joseph Laia

Los Alamos National Laboratory

P.0. Box 1663

Los Alamos, NM 87545

(505) 667-6887

Ron Lang

for Manufacturing

Sciences

900 Victors Way

Ann Arbor, MI 48108-1779

(313) 995-0300

(313) 995-4004, FAX

Dan Maas

National Center for Manufacturing

Sciences

900 Victors Way

(313) 995-0300

(313) 995-4004, FAX

B. 1 
John Petrovic

Los Alamos National Laboratory

P.0. Box 1663, G771

Los Alamos, NM 87545

(505) 667-0125

(505) 665-3363, FAX

Robert Reynolds

National Center for Manufacturing Sciences

900 Victors Way

Ann Arbor, MI 48108-1779

(313) 995-0300

(313) 995-4004, FAX

Ronald Roberts

Patent and Legal Liason

GM Corp.

Advanced Engineering Staff

GM Tech Center, A/MD-28

3300 Mound Road

Warren, MI 48090-9040

Dale Schaefer

Sandia National Laboratory

Dept. 1810

P.0. Box 5800

1515 Eubanks SE

Albuquerque, NM 87185

(505) $844-7937$

(505) $846-5064$, FAX

John Sheridan

National Center for Manufacturing Sciences

900 Victors Way

Ann Arbor, MI 48108-1779

(313) $995-0300$

(313) $995-4004$, FAX

Mark Smiti

Sandia National Laboratory

P.0. Box 5800

1515 Eubanks SE

Albuquerque, NM

87185
Al Sylwester

Sandia National Laboratories

Division 6211

P.0. Box 5800

Albuquerque, NM 87185

(505) 844-8151

(505) $844-7786$, FAX

Charles Sorre 11, Program Manager

Advanced Industrial Materials Program

Advanced Industrial Concepts Division

U.S. Department of Energy

Mail Stop CE-232

1000 Independence Ave., SW

Washington, D.C. 20585

(202) $586-1514$

(202) $586-7114$, FAX

Clare Vinton

National Center for Manufacturing

Sciences

900 Victors Way

Ann Arbor, MI 48108-1779

(313) 995-0300

(313) 995-4004, FAX

Don Walukas

National Center for Manufacturing Sciences

900 Victors Way

Ann Arbor, MI 48108-1779

(313) $995-0300$

(313) 995-4004, FAX

Nick Weil

National Center for Manufacturing Sciences

900 Victors Way

Ann Arbor, MI 48108-1779

(313) $995-0300$

(313) $995-4004, F A X$

Michael Wixom

National Center for Manufacturing Sciences

900 Victors Way

Ann Arbor, MI 48108-1779

(313) $995-0300$

(313) 995-4004, FAX 
PNL -8218

UC -310

\section{DISTRIBUTION}

No. of

No. of

Copies

Copies

\section{OFFSITE}

12 DOE/Office of Scientific and Technical Information

\section{R. Abarcar}

Energetics, Inc.

7164 Gateway Drive

Columbia, MD 21046

6 Advanced Industrial Concepts

Division

Office of Industrial

$$
\text { Technologies }
$$

Forrestal Building/CE-232

1000 Independence Ave., S.W.

Washington, DC 20585

ATTN: D. J. Boron

M. E. Gunn, Jr.

C. Sorrel1

Ehr-Ping Huang $\mathrm{Fu}$

B. Volintine

D. K. Walter

J. E. Anderson

Principal Research Scientist

Ford Motor Company

Scientific Research Laboratory

21500 0akwood B1vd.

Dearborn, MI 48121-2053

D. R. Andres

Manager, Advanced Purchasing

General Motors Corporation

Saginaw Division

3900 Holland Road

Saginaw, MI 48601-9494
P. Angel ini

Oak Ridge National Laboratory

P.0. Box 2008

Building 4515

Oak Ridge, TN 37831-6065

K. J. Barnett

National Center for

Manufacturing Sciences

900 Victors Way

Ann Arbor, MI 48108-1779

H. Chum

National Renewable Energy Laboratory

Chemical Technologies Research Branch

1617 Cole Blvd.

Golden, CO 80401-3393

J. J. Eberhardt

Office of Transportation

Materials

Office of Transportation

Technologies

Forrestal Building

1000 Independence Ave., S.W.

Washington, DC 20585

M. Epstein

Motor Vehicle Manufacturers

Association

7430 Second Avenue, Suite 300

Detroit, MI 48202

K. Friedman

Office of Industrial

Technologies

Forrestal Building/CE-20

1000 Independence Ave., S.W.

Washington, DC 20585 
No. of

Copies

J. Laia

Los Alamos National Laboratory

P.0. Box 1663

Los Alamos, NM 87545

R. Lang

National Center for

Manufacturing Sciences

900 Victors Way

Ann Arbor, MI 48108-1779

D. Maas

National Center for

Manufacturing Sciences

900 Victors Way

Ann Arbor, MI 48108-1779

J. Petrovic

Los Alamos National Laboratory

P.0. Box 1663, G771

Los Alamos, NM 87545

R. Reynolds

National Center for Manufacturing Sciences

900 Victors Way

Ann Arbor, MI 48108-1779

R. Roberts

Patent and Legal Liason

GM Corp.

Advanced Engineering Staff

GM Tech Center, A/MD-28

3300 Mound Road

Warren, MI 48090-9040

P. Roth

Energetics, Inc.

7164 Gateway Drive

Columbia, MD 21046

P. Salmon-Cox

Office of Industrial

Technologies

Forrestal Building/CE-23

1000 Independence Ave., S.W.

Washington, DC 20585
No. of

Copies

L. B. Schilling

Improved Energy Productivity

Division

Office of Industrial

Technologies

Forrestal Building/CE-231

1000 Independence Ave., S.W.

Washington, DC 20585

D. Schaefer

Sandia National Laboratory

Dept. 1810

P.0. Box 5800

1515 Eubanks SE

Albuquerque, NM 87185

R. K. Sen

R. K. Sen \& Associates

3808 Veazey St. N.W.

Washington, DC 20016

J. Sheridan

National Center for Manufacturing Sciences

900 Victors Way

Ann Arbor, MI 48108-1779

M. Smith

Sandia National Laboratory

P.0. Box 5800

1515 Eubanks SE

Albuquerque, NM 87185

C. Sorre 11, Program Manager

Advanced Industrial Materials Program

Advanced Industrial Concepts Division

Forrestal Building/CE-232

1000 Independence Ave., SW

Washington, D.C. 20585

Distr.2 
No. of Copies

\author{
A. J. Streb \\ Office of Industrial \\ Technologies \\ Forrestal Building/CE-20 \\ 1000 Independence Ave., S.W. \\ Washington, DC 20585

\section{Swink \\ Technologies \\ Forrestal Building/CE-20} \\ Office of Industrial \\ 1000 Independence Ave., S.W. \\ Washington, DC 20585
}
A. Sylwester
Sandia National Labcratories Division 6211
P.0. Box 5800
Albuquerque, NM 87185
C. Vinton
National Center for
Manufacturing Sciences
900 Victors Way
Ann Arbor, MI 48108-1779
D. Walukas
National Center for
Manufacturing Sciences
900 Victors Way
Ann Arbor, MI $48108-1779$
N. Weil
National Center for
Manufacturing Sciences
900 Victors Way
Ann Arbor, MI 48108-1779
D. E. Wiley
Improved Energy Productivity Division
office of Industrial
Technologies
Forrestal Building/CE-231
1000 Independence Ave., S.W.
Washington, DC 20585

No. of

Copies

\author{
M. Wixom \\ National Center for \\ Manufi,turing Sciences \\ 900 Victors Way \\ Ann Arbor, MI 48108-1779
}

\section{ONSITE}

\section{DOE Richland Field office}

R. B. Goranson

33 Pacific Northwest Laboratory

W. B. Ashton

E. G. Baker

R. S. Butner

D. E. Deonigi

J. A. Dirks

K. K. Daellenbach

L. L. Fassbender

C. A. Geffen

B. A. Garrett

J. A. Jaksch

D. A. Seaver

S. A. Weakley

J. K. Young (15)

Publishing Coordination

Technical Report Files (5) 

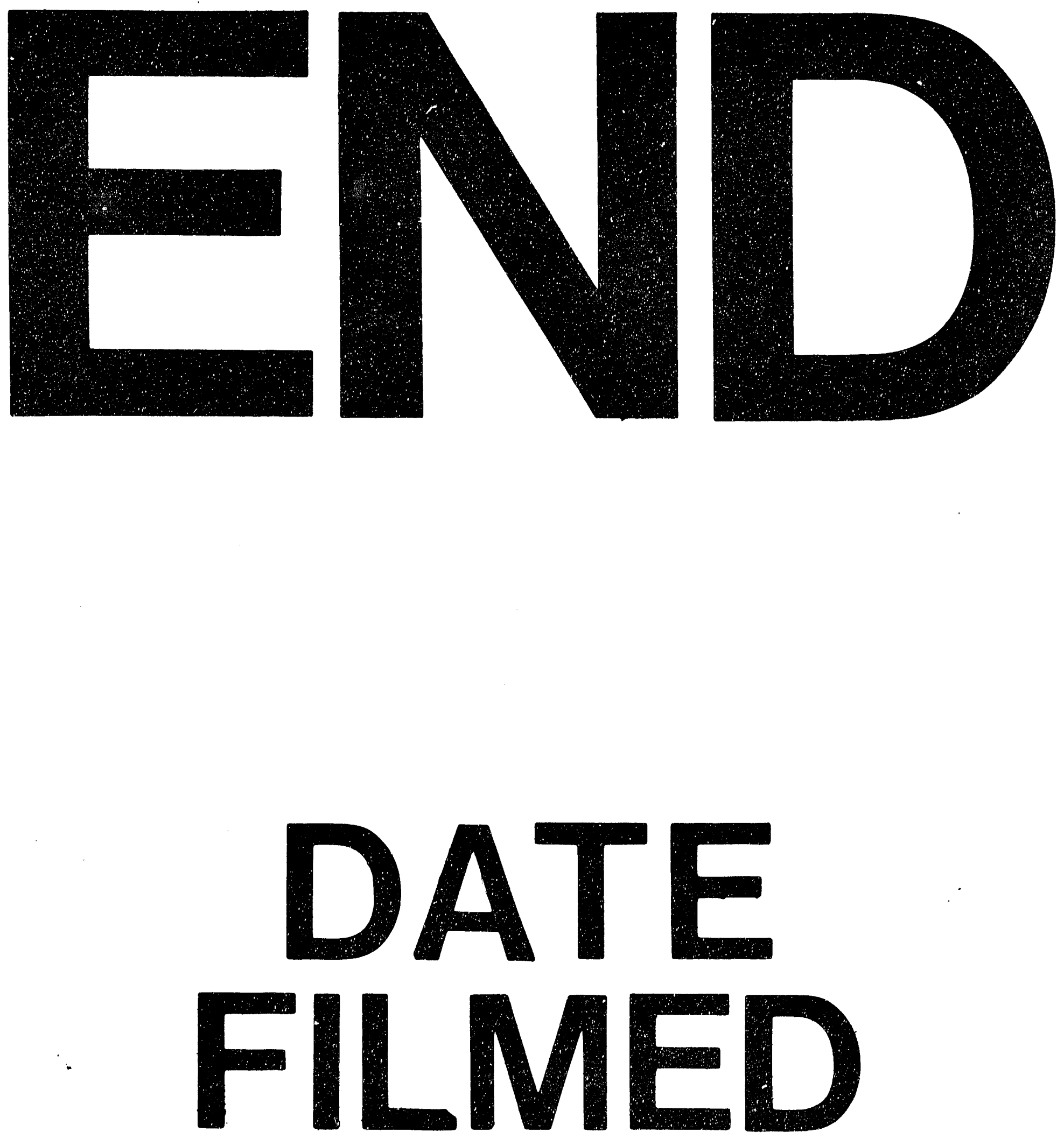

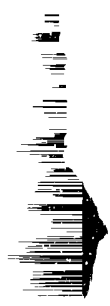

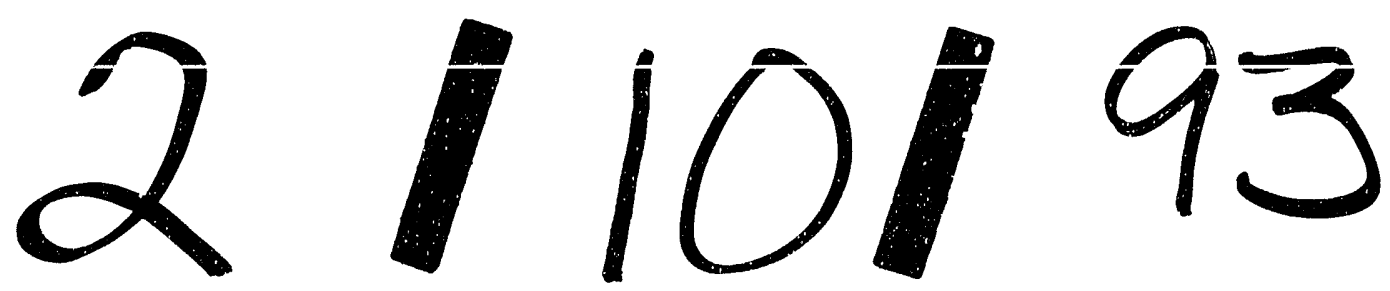


